Precipitation, Ground-water Hydrology, and Recharge Along the Eastern Slopes of the Sandia Mountains, Bernalillo County, New Mexico 



\title{
Precipitation, Ground-water Hydrology, and Recharge Along the Eastern Slopes of the Sandia Mountains, Bernalillo County, New Mexico
}

\author{
By Kurt J. McCoy and Paul J. Blanchard
}

In cooperation with Bernalillo County Public Works Division

Scientific Investigations Report 2008-5179 


\title{
U.S. Department of the Interior DIRK KEMPTHORNE, Secretary
}

\author{
U.S. Geological Survey \\ Mark D. Myers, Director
}

U.S. Geological Survey, Reston, Virginia: 2008

This and other USGS information products are available at http://store.usgs.gov/

U.S. Geological Survey

Box 25286, Denver Federal Center

Denver, CO 80225

To learn about the USGS and its information products visit http://www.usgs.gov/ 1-888-ASK-USGS

Any use of trade, product, or firm names is for descriptive purposes only and does not imply endorsement by the U.S. Government.

Although this report is in the public domain, permission must be secured from the individual copyright owners to reproduce any copyrighted materials contained within this report.

Suggested citation:

McCoy, Kurt J., and Blanchard, Paul J., 2008, Precipitation, ground-water hydrology, and recharge along the eastern slopes of the Sandia Mountains, Bernalillo County, New Mexico: U.S. Geological Survey Scientific Investigations Report 2008-5179, 34 p. 


\section{Contents}

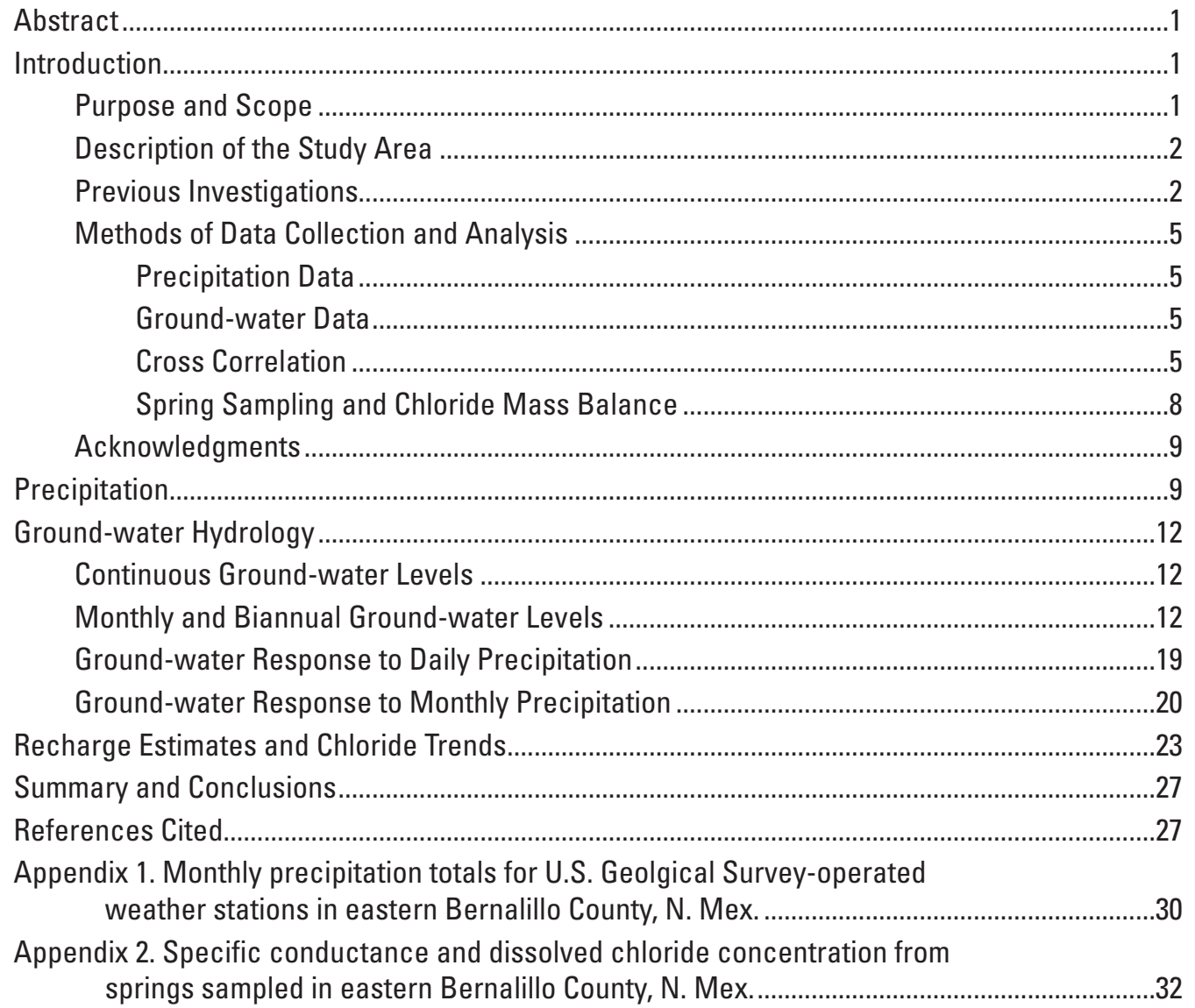

\section{Figures}

1. Map showing location of study area and data-collection sites, eastern

Bernalillo County, N. Mex...........................................................................................

2. Geologic map of the study area in eastern Bernalillo County, N. Mex.................................

3. Example cross-correlation plot (bottom) for hypothetical precipitation and water-level time series (top) ..................................................................................

4. Annual precipitation compared to elevation for eastern Bernalillo County, N. Mex.

5. Mean monthly precipitation data from NOAA precipitation sites 1963 to 1974 for the Sandia Mountains of central New Mexico

6. Water-level and precipitation data from continuous monitoring sites in eastern Bernalillo County, N. Mex

7. Monthly and biannual water-level data from synoptic-well network in eastern Bernalillo County, N. Mex

8. Cross-correlogram between daily precipitation at site 2 and water level at well 12 for 2006 data 
9. Cross-correlogram between daily precipitation at site 2 and water

level at well 15 for 2006 data

10. Lag time absolute values for cross correlation of monthly precipitation and water levels in wells of eastern Bernalillo County, N. Mex., 1990 to 1992

11. Lag time absolute values for cross correlation of monthly precipitation and dissolved chloride in wells of eastern Bernalillo County, N. Mex., 1990 to 1992.

12. Lag time absolute values for cross correlation of monthly precipitation and specific conductance in wells of eastern Bernalillo County, N. Mex., 1990 to 1992.

13. Dissolved-chloride concentration in spring water samples collected from eastern Bernalillo County, N. Mex.

\section{Tables}

1. Data for precipitation sites in eastern Bernalillo County, N. Mex.

2. Site data for monitoring wells and springs in eastern Bernalillo County,

N. Mex.

3. Snow-survey data collected by the U.S. Geological Survey at site 1 near Sandia Crest, N. Mex.

4. Cross correlation indicating lag time statistically significant lag times between monthly precipitation and water levels, dissolved chloride, and specific conductance in wells of eastern Bernalillo County, N. Mex., 1990 to 1992

5. Median, minimum, maximum, and range of percent recharge at selected springs estimated by using the chloride mass balance technique 


\section{Conversion Factors and Datums}

\begin{tabular}{|c|c|c|}
\hline Multiply & By & To obtain \\
\hline \multicolumn{3}{|c|}{ Length } \\
\hline inch (in.) & 2.54 & centimeter $(\mathrm{cm})$ \\
\hline inch (in.) & 25.4 & millimeter $(\mathrm{mm})$ \\
\hline foot (ft) & 0.3048 & meter $(\mathrm{m})$ \\
\hline mile (mi) & 1.609 & kilometer $(\mathrm{km})$ \\
\hline \multicolumn{3}{|c|}{ Area } \\
\hline acre & 0.004047 & square kilometer $\left(\mathrm{km}^{2}\right)$ \\
\hline square mile $\left(\mathrm{mi}^{2}\right)$ & 2.590 & square kilometer $\left(\mathrm{km}^{2}\right)$ \\
\hline \multicolumn{3}{|c|}{ Volume } \\
\hline gallon (gal) & 3.785 & liter (L) \\
\hline gallon (gal) & 0.003785 & cubic meter $\left(\mathrm{m}^{3}\right)$ \\
\hline cubic foot $\left(\mathrm{ft}^{3}\right)$ & 0.02832 & cubic meter $\left(\mathrm{m}^{3}\right)$ \\
\hline \multicolumn{3}{|c|}{ Flow rate } \\
\hline foot per day $(\mathrm{ft} / \mathrm{d})$ & 0.3048 & meter per day $(\mathrm{m} / \mathrm{d})$ \\
\hline cubic foot per second $\left(\mathrm{ft}^{3} / \mathrm{s}\right)$ & 0.02832 & cubic meter per second $\left(\mathrm{m}^{3} / \mathrm{s}\right)$ \\
\hline cubic foot per day $\left(\mathrm{ft}^{3} / \mathrm{d}\right)$ & 0.02832 & cubic meter per day $\left(\mathrm{m}^{3} / \mathrm{d}\right)$ \\
\hline gallon per minute (gal/min) & 0.06309 & liter per second $(\mathrm{L} / \mathrm{s})$ \\
\hline gallons per day (gal/d) & 0.003785 & cubic meter per day $\left(\mathrm{m}^{3} / \mathrm{d}\right)$ \\
\hline inch per year (in/yr) & 25.4 & millimeter per year $(\mathrm{mm} / \mathrm{yr})$ \\
\hline
\end{tabular}

Vertical coordinate information is referenced to the North American Vertical Datum of 1988 (NAVD 88), and horizontal coordinate information is referenced to the North American Datum of 1983 (NAD 83). 



\title{
Precipitation, Ground-water Hydrology, and Recharge Along the Eastern Slopes of the Sandia Mountains, Bernalillo County, New Mexico
}

\author{
By Kurt J. McCoy and Paul J. Blanchard
}

\section{Abstract}

The spatial and temporal distribution of recharge to carbonate and clastic aquifers along the eastern slopes of the Sandia Mountains was investigated by using precipitation, water-level, dissolved chloride, and specific-conductance data. The U.S. Geological Survey (USGS), in cooperation with the Bernalillo County Public Works Division, conducted a study to assess ground-water conditions and provide technical data that could be used as a basis for management and future planning of eastern Bernalillo County water resources. The intent of the investigation was to improve the current understanding of subsurface mechanisms controlling recharge dynamics in a geologically complex aquifer system. In the Sandia Mountains, precipitation events are generally limited to snowfalls in winter months and monsoon rainfall in late summer. Monthly meteorological data from weather stations in the study area indicate that monsoon rainfall during July and August constitutes close to one-third of annual precipitation totals. Following precipitation and snowmelt events, daily ground-water level data show low-amplitude, long-duration peaks in hydrographs of wells north and west of the Tijeras Fault. Hydrographs of monthly and biannual water-level data from across the study area show seasonal variation and water-level fluctuations in excess of $30 \mathrm{ft}$ during a period of below-average precipitation. Water level observations in 67 percent of wells showing drought-induced water-level declines rebounded to at or near predrought conditions within 6 months of return to normal climate conditions. Cross-correlation of annual hydrologic data shows aquifer response to periods of monsoon recharge to persist from 1 to 6 months following events. The lag time between precipitation input and response of water levels or solute concentrations was largest near the Tijeras and Gutierrez Faults. These results indicate regional faults hydrologically isolate the Tijeras Graben from groundwater recharge originating at high elevations along the eastern slopes of the Sandia Mountains. Recharge rates calculated by using the chloride-mass-balance method for five springs located at the base of the Sandia Mountains ranged from 1 to 23 percent of annual precipitation.

\section{Introduction}

Recent expansion of suburban development and subsequent population growth in the Sandia Mountains of eastern Bernalillo County, New Mexico, has led to increased construction of homes and businesses with commensurate demands on available ground-water supplies. Information regarding the spatial and temporal variability in recharge is needed for protection of aquifer health and for allowance of continued population and economic growth. Planning for future withdrawals from aquifers of eastern Bernalillo County requires rigorous estimates of the percentage of precipitation reaching phreatic zones in addition to a fundamental knowledge of the distribution, timing, and mechanisms of infiltration following precipitation. Cross correlation of timeseries data has shown the ability to provide such insight into recharge mechanisms (Lee and Lee, 2000), pathways (Lee and others, 2006), and regional hydrodynamics (Larocque and others, 1998) in clastic and carbonate aquifers.

The U.S. Geological Survey (USGS), in cooperation with the Bernalillo County Public Works Division, has conducted a study to assess ground-water conditions and provide technical data that could be used as a basis for management and future planning of eastern Bernalillo County water resources. Hydrologic time-series data collected by the USGS in eastern Bernalillo County are used to address annual variability in water levels and geochemical data measured since 1990 and to provide estimates of recharge to upland springs.

\section{Purpose and Scope}

The purpose of this report is to describe precipitation, ground-water hydrology, and recharge along the eastern slopes of the Sandia Mountains and provide information to improve the understanding of recharge dynamics in aquifers of the East Mountain area (EMA) in Bernalillo County, New Mexico. The scope of this study included collection of precipitation data at six sites from 2001-07; biannual measurement of water levels in the EMA synoptic network from 2002-07; hourly automated measurement of water levels in five wells 
from 2005-07; and biannual collection and analysis of water samples for chloride concentrations from five springs from 2005-07. A monthly hydrologic dataset of precipitation, ground-water levels, and water-quality samples collected from 1990-93 also was compiled. Cross correlation and chloridemass-balance analyses were used to evaluate the response of the aquifer to precipitation inputs. The report focuses on recharge related to monsoon summer precipitation because adequate data are not available to address recharge related to snowmelt.

\section{Description of the Study Area}

The study area includes the EMA and consists of approximately $260 \mathrm{mi}^{2}$, which includes all of Bernalillo County east of the crests of the Sandia and Manzanita Mountains (fig. 1). The geology of the EMA increases in complexity from south to north (fig. 2). This change in complexity is the result of differing degrees of structural deformation between the Manzanita Mountains in the south and the Sandia Mountains in the north (Read and others, 1995; Ferguson and others, 1996; Allen, 2002, 2003). The southern terminus of the Sandia Mountains is separated from the northern terminus of the Manzanita Mountains by a structural transition zone marked by the Tijeras and Gutierrez Faults (fig. 2). These faults extend from southwest to northeast approximately coincident with the U.S. Interstate Highway 40 (I-40) corridor through Tijeras Canyon (Karlstrom and others, 1994). Igneous and metamorphic rocks of Proterozoic age are exposed in Tijeras Canyon west of the village of Tijeras (Kelley and Northrop, 1975).

Throughout most of the area south of the Tijeras Fault zone, the uppermost consolidated geologic unit is the Madera Formation of Pennsylvanian age. North of the Tijeras Fault zone, the uppermost consolidated geologic units range from the Madera Formation to the Mesa Verde Group of Cretaceous age. Outcrops of carbonate and clastic rocks consisting of the Yeso Formation, San Andres Limestone, and Glorieta Sandstone of Permian age, the Chinle Formation of Triassic age, and the Dakota Sandstone of Cretaceous age trend southwest to northeast in the Tijeras Graben, a downfaulted and folded structure ranging from less than 1 to more than 5 miles wide through the center of the study area. Bounded to the west by the Tijeras Fault and to the east by the Gutierrez Fault (Karlstrom and others, 1994; Ferguson and others, 1996), the Tijeras Graben exposes shales and sandstones that have a wide range of hydrologic characteristics (Titus, 1980).

Alluvial deposits of silts, sands, and gravels of Quaternary age overlie bedrock surfaces in topographically low areas along arroyos (Read and others, 1995; Ferguson and others, 1996; Allen, 2002, 2003). Alluvial thicknesses are as much as $100 \mathrm{ft}$ in Tijeras Canyon and 30-90 ft in drainages near Sandia Park (Titus, 1980). Alluvial deposits are saturated by direct runoff from seasonal precipitation and by discharge from adjacent bedrock aquifers. In the Manzanita Mountains, locally thick unsaturated alluvium may be found above the water table (Titus, 1980). To the east of the study area, extensive deposits of valley-fill alluvium crop out along the edge of the Estancia Basin (Kelley and Northrop, 1975).

Ground-water hydrology throughout the study area is strongly influenced by individual faults and fault zones where offsets of hundreds of feet may juxtapose geologic units having differing hydrologic properties (Drakos, 1999). Springs on the lower eastern slopes of the Sandia Mountains from Tijeras Canyon north to Sandia Park indicate that precipitation recharging the ground-water system in the Sandia Mountains moves eastward to discharge points located along faults. Eastward draining springs are less numerous in the Manzanita Mountains (White and Kues, 1992) where the strata are gently dipping, average 1-2 degrees, and less frequently faulted than in the Sandia Mountains (Kelley and Northrop, 1975). Manzanita Mountain springs commonly discharge along joints or where alluvium wedges out against bedrock (White and Kues, 1992). Downgradient from springs in both mountain ranges, water can infiltrate to the subsurface through alluvial deposits and, in cases, recharge underlying bedrock aquifers.

\section{Previous Investigations}

Titus (1980) was the first to discuss the relations between geology and ground-water supply and quality in the Sandia Mountains of New Mexico. Based on an evaluation of well yields and water quality of the area, Titus (1980) defined seven hydrostructural domains in the EMA bounded by lithologic and structural discontinuities. His observations of order of magnitude variability of well yields within individual terrains and inability to find ground-water supplies adequate for large withdrawals were later corroborated by Kues (1990). Low-yielding aquifers also were found by Drakos and others (1999) who reported a potential for domestic dewatering of an approximately $0.6-\mathrm{mi}^{2}$ fault-bounded structural block near Zuzax, New Mexico.

In a comparison of ground-water levels since Titus' (1980) study, Kues (1990) noted isolated declines of approximately $30-150 \mathrm{ft}$ in wells completed in black shale units of the upper Madera Formation near Barton, New Mexico. In some cases, steep seasonal declines in water levels were generally followed by recovery within 7-9 months (Kues, 1990). Seasonal to annual variations of $10-60 \mathrm{ft}$ were common in many of the wells later sampled by Kues and Garcia (1995) over a 3-year period from 1990-93. Blanchard (2004) recorded annual variations of 0-18 ft from 2002-03. Annual water-level variability in one well near Sandia Park was correlated to rainfall with a 2.5-year lag time (Kues, 1990). Using higher frequency sampling, Blanchard and Kues (1999) observed an apparent lag time of 1 month in 16 wells across the EMA following 7.4 inches of precipitation in July 1991. Ground-water age in the EMA was estimated by using chlorofluorocarbon (CFC) analyses to be 10-16 years in alluvial aquifers and 16-26 years in fractured rock aquifers (Blanchard, 2004). 


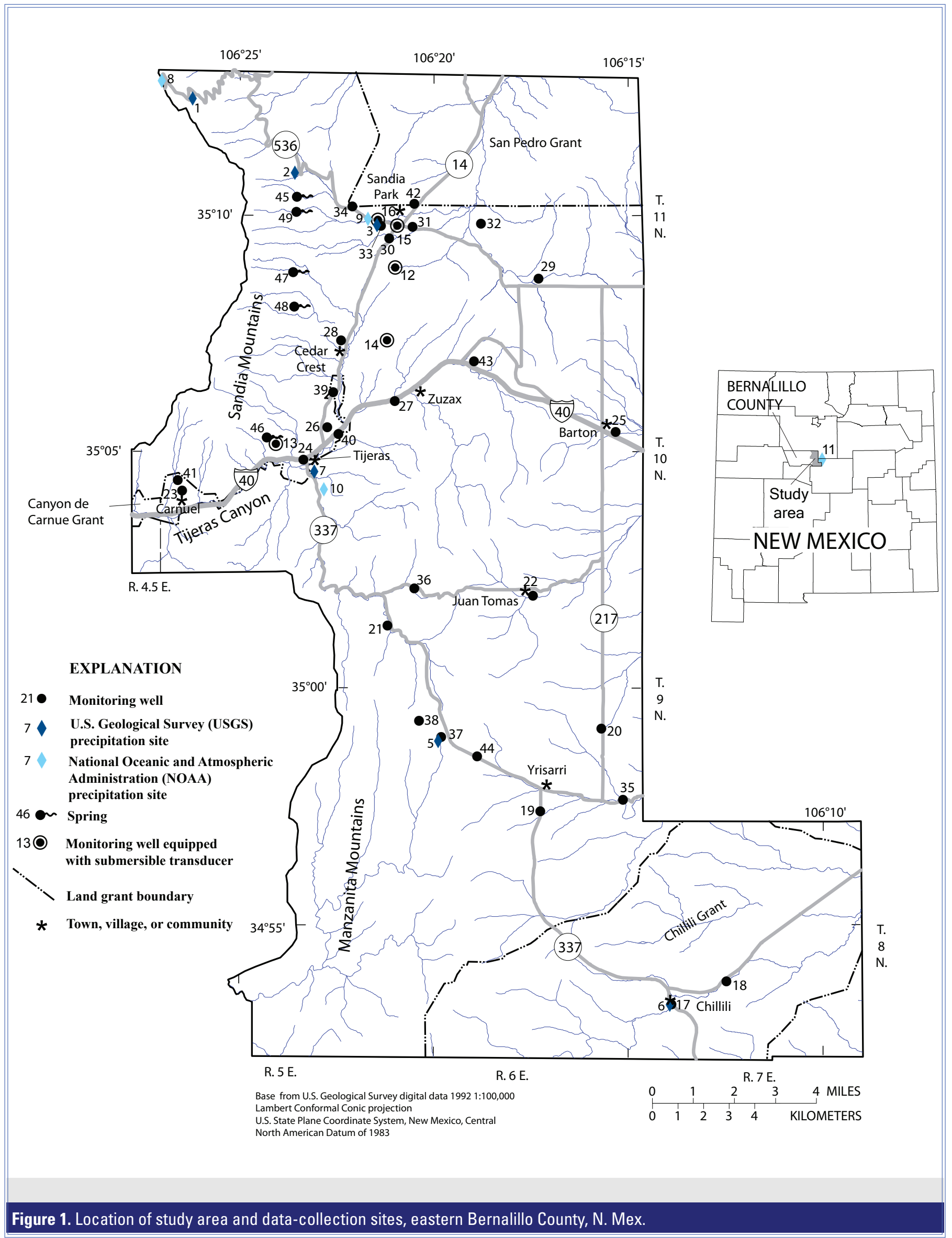




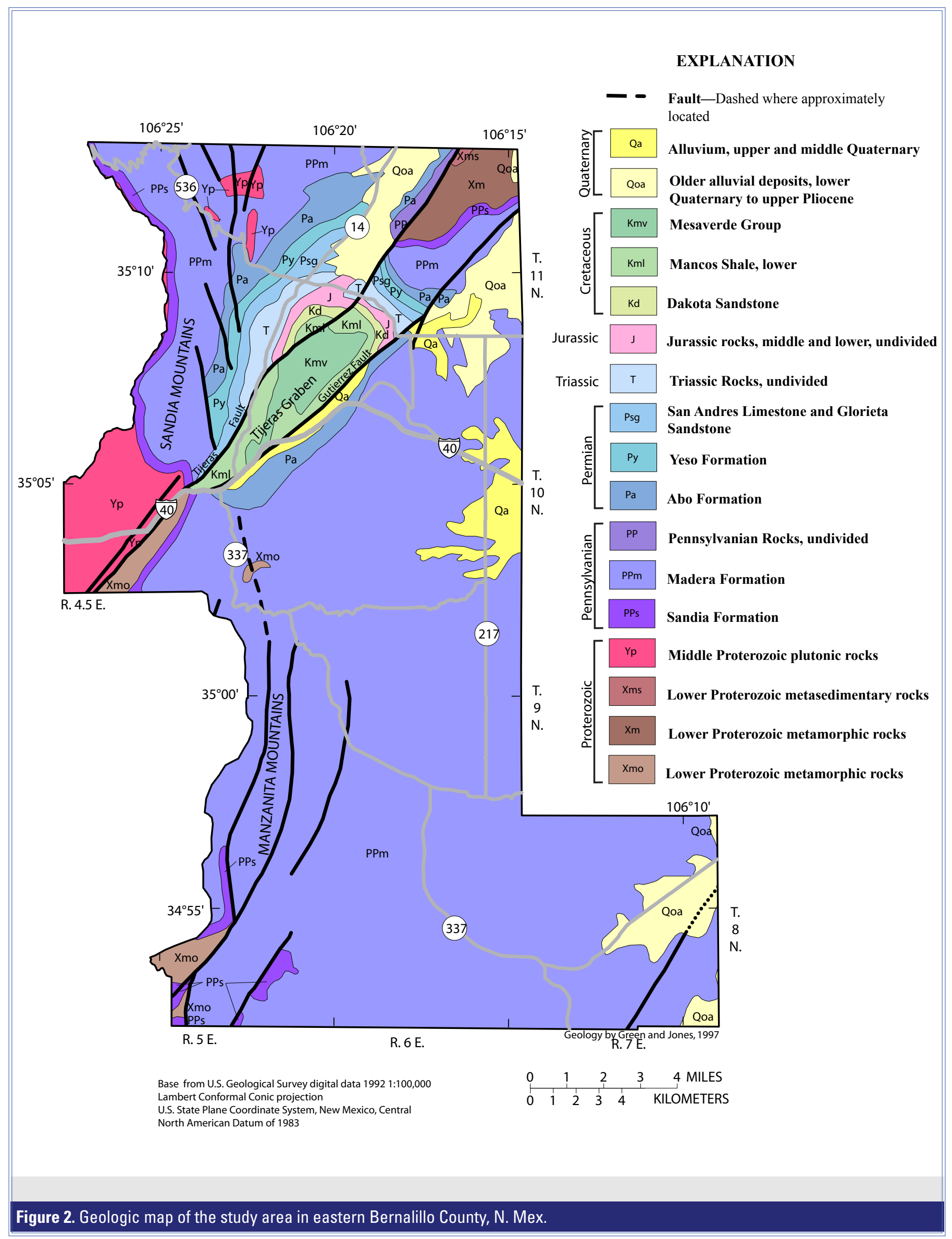




\section{Methods of Data Collection and Analysis}

\section{Precipitation Data}

Beginning in 2001, hourly precipitation data were collected by the USGS at five sites by using Texas Electronics TS-525 tipping bucket rain gages mounted on 10-ft triangular towers (table 1). Additional precipitation data were collected by the USGS at one volunteer station (site 7) established in the village of Tijeras (fig. 1). Data collected at the six sites were downloaded every 3 months, reviewed, and entered into the USGS National Water Information System (NWIS) database. Supplemental precipitation data were compiled from four sites (fig. 1) in eastern Bernalillo County operated by the National Oceanic and Atmospheric Administration (NOAA) (table 1).

\section{Ground-water Data}

Hourly water levels were measured with continuous data recorders in wells 12-16 from 2005-07 (fig. 1, table 2). Biannual water-level measurements were recorded at wells 17-36 from 2002 to 2007. This network of 20 wells across the EMA consisted of 12 wells previously measured and sampled by Kues and Garcia (1995) from 1990-93 (wells 17, 21, 23-28, 30 , and 32-34). Additional ground-water level and waterquality records from 1990-93 were compiled from wells 37-44 (Kues and Garcia, 1995).

Monthly and biannual water levels were measured manually with a steel tape to the nearest one-hundredth of 1 foot. An electric tape was substituted for the steel tape in wells where depth to water could not successfully be determined with the steel tape, typically because of moisture inside the well casing. At each visit, two water-level measurements were made, at least 5 minutes apart, to detect any short-term water-level fluctuation attributed to recent pumpage.

\section{Cross Correlation}

Cross correlation is a time-series analysis technique to define the time-lagged interrelation of two datasets. A correlogram of precipitation and ground-water levels or solute concentrations can reveal the significance of aquifer response to a climatic input and the time taken for response to precipitation to be calculated (Lee and others, 2006). The cross-correlation coefficient at time lag $m$ is calculated by using the following relation (Davis, 2002):

$$
r_{m}=\frac{n * \sum Y_{1} Y_{2}-\sum Y_{1} \sum Y_{2}}{\sqrt{\left[n * \sum Y_{1}^{2}-\left(\sum Y_{1}\right)\right]\left[n * \sum Y_{2}^{2}-\left(\sum Y_{2}\right)\right]}}
$$

where, $r_{m} \quad$ is the cross correlation coefficient at time lag $m$;

$m \quad$ is the time lag between two time series (days, months, etc.);

$n^{*} \quad$ is the number of overlapping data points;

$Y_{1} \quad$ is the observed input data (precipitation);

$Y_{2} \quad$ is the observed output data (water level, chloride concentration, or specific conductance).

Table 1. Data for precipitation sites in eastern Bernalillo County, N. Mex.

[Site locations shown in fig. 1. Abbreviations: ft, feet above NAVD 88; USGS, U.S. Geological Survey; NOAA, National Oceanic and Atmospheric Administration; ${ }^{\circ}$, degrees; ', minutes; ", seconds]

\begin{tabular}{|c|c|c|c|c|c|c|c|c|}
\hline $\begin{array}{c}\text { Site } \\
\text { number }\end{array}$ & $\begin{array}{l}\text { USGS station } \\
\text { identification } \\
\text { number }\end{array}$ & Station name & Latitude & Longitude & Datum & $\begin{array}{l}\text { Elevation } \\
\text { (ft) }\end{array}$ & Operating agency & $\begin{array}{l}\text { Period of } \\
\text { record } \\
\text { (calendar } \\
\text { years) }{ }^{1}\end{array}$ \\
\hline 1 & 351228106261130 & Upper Sandia & $35^{\circ} 12^{\prime} 28^{\prime \prime}$ & $106^{\circ} 26^{\prime} 11^{\prime \prime}$ & NAD83 & 10,030 & USGS & 2001-07 \\
\hline 2 & 351054106233330 & Middle Sandia & $35^{\circ} 10^{\prime} 54^{\prime \prime}$ & $106^{\circ} 23^{\prime} 33^{\prime \prime}$ & NAD83 & 8,020 & USGS & 2001-07 \\
\hline 3 & 350948106212630 & Lower Sandia & $35^{\circ} 09^{\prime} 48^{\prime \prime}$ & $106^{\circ} 21^{\prime} 26^{\prime \prime}$ & NAD83 & 7,030 & USGS & 2001-07 \\
\hline 5 & 345853106195130 & Middle Manzanita & $34^{\circ} 58^{\prime} 53^{\prime \prime}$ & $106^{\circ} 19^{\prime} 51^{\prime \prime}$ & NAD83 & 7,460 & USGS & 2001-07 \\
\hline 6 & 345318106135430 & Lower Manzanita & $34^{\circ} 53^{\prime} 18^{\prime \prime}$ & $106^{\circ} 13^{\prime} 54^{\prime \prime}$ & NAD83 & 6,780 & USGS & 2001-07 \\
\hline 7 & 350434106230501 & Tijeras volunteer & $35^{\circ} 04^{\prime} 41^{\prime \prime}$ & $106^{\circ} 23^{\prime} 05^{\prime \prime}$ & NAD83 & 6,350 & USGS & 2001-07 \\
\hline 8 & 298011 & Sandia Crest & $35^{\circ} 13^{\prime}$ & $106^{\circ} 27^{\prime}$ & NAD83 & 10,686 & NOAA & $1953-79$ \\
\hline 9 & 298015 & Sandia Park & $35^{\circ} 13^{\prime}$ & $106^{\circ} 22^{\prime}$ & NAD83 & 7,019 & NOAA & 1946-2007 \\
\hline 10 & 298018 & Sandia Rs & $35^{\circ} 04^{\prime}$ & $106^{\circ} 23^{\prime}$ & NAD83 & 6,306 & NOAA & 1931-75 \\
\hline 11 & 292751 & Edgewood & $35^{\circ} 03^{\prime}$ & $106^{\circ} 08^{\prime}$ & NAD83 & 6,804 & NOAA & $1946-59$ \\
\hline
\end{tabular}

${ }^{1}$ Discontinuous record and data gaps may exist within bracketed years. 


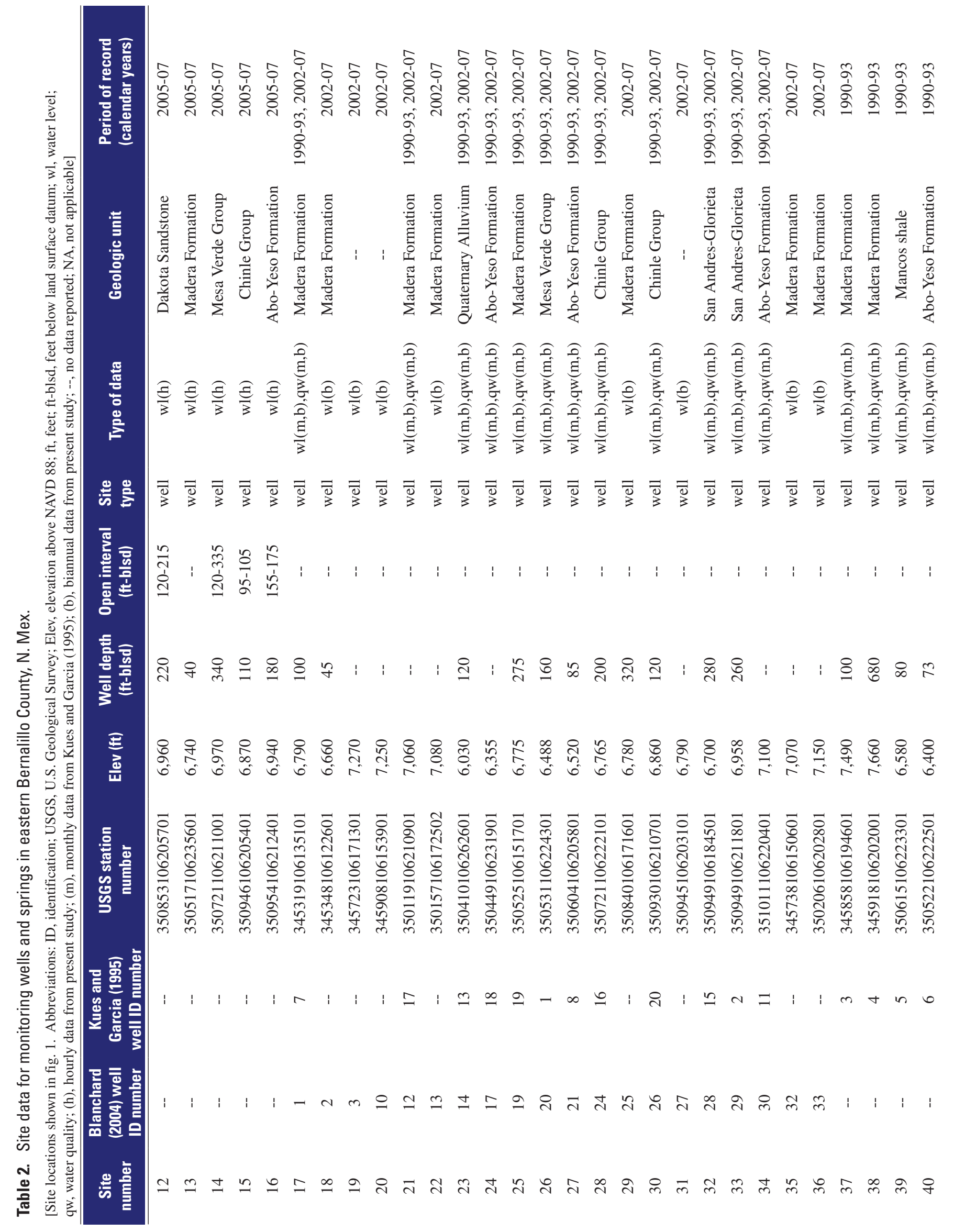




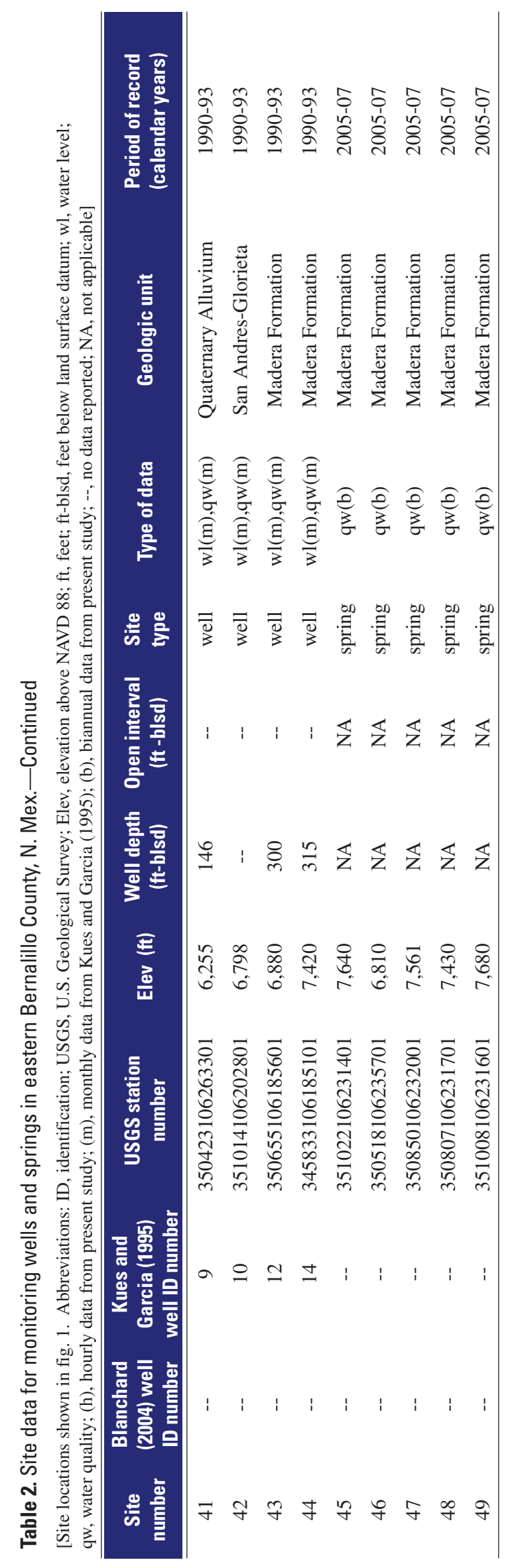


Significant lag-time correlations at the 95 percent confidence level are those in which $r_{m}$ exceeds the standard error of $2 /\left(\mathrm{N}^{1 / 2}\right)$, where $\mathrm{N}$ is the length of the dataset (Diggle, 1990; Lee and others, 2006).

An example cross-correlation between hypothetical precipitation and water-level data sets is shown in figure 3 to illustrate the utility of this type of time-series analysis. Rainfall at the beginning of the period is followed by 9 days of water-level decline. The water level begins to rise on day 10 and continues until reaching a peak value on day 11 . The correlation is negative for 9 days until the recharge resulting from the rainfall reaches the aquifer on day 10 , or a lag time of 10 days following the event. The positive correlations at lag time 11 and 12 days are statistically significant. As the water level begins to decline, the correlation again falls below the 95 percent confidence level.

Statistically significant negative correlations between precipitation and water levels represent periods when the two time-series data are out of phase (Larocque and others, 1998; Lee and others, 2006). For example, the negative correlation for the initial 9 days in figure 3 is the result of precipitation, or a positive change in precipitation, correlated to a decrease in water levels at the time of and immediately following the event. When the water level increases on day 10 , the positive precipitation event is positively correlated to a rise, or an increase, in water levels. For this example, the negative correlation, or the period when the two time series are out of phase, has no physical meaning; water levels cannot decrease in response to a recharge event. In the case of solute concentrations, however, negative correlations represent an inverse relation between two time-series datasets that may have meaning with regards to solute flushing or rapid influx of dilute recharge moving through the aquifer.

\section{Spring Sampling and Chloride Mass Balance}

Water-quality samples were collected biannually from five springs on the eastern slopes of the Sandia Mountains to evaluate variation in chloride concentration and estimate recharge rates (sites 45-49) (fig. 1, table 2). Field measurements of water temperature and specific conductance were recorded during each sampling visit. Following sample collection, water samples were filtered by using a 0.45 -micron capsule filter and then shipped to the USGS National WaterQuality Laboratory (NWQL), Denver, Colo., for analysis of specific conductance, $\mathrm{pH}$, and dissolved chloride.

Chloride concentrations in the unsaturated zone and in ground water have been used by investigators to determine recharge rates in the arid southwest (Anderholm, 1994, 2000; Phillips, 1994). Most chloride in ground water is derived from precipitation, although chloride can be dissolved from salts accumulated in the unsaturated zone or from strata such as the Madera Formation which were deposited in a marine environment. Chloride ions move through the hydrologic system nearly exclusively by physical processes (Hem, 1985). Because chloride is chemically conservative, concentrations in ground water greater than concentrations in precipitation indicate that while in the vadose zone either (1) the volume of water in the system has decreased because of evapotranspiration, or (2) infiltrating water has dissolved chloride ions originating from dry deposition, from marine sediments, or a combination of these processes. Infiltration of subsequent precipitation water may flush all or part of the chloride deeper into the vadose zone. This cycle may continue any number of times before some of the water recharges the aquifer.
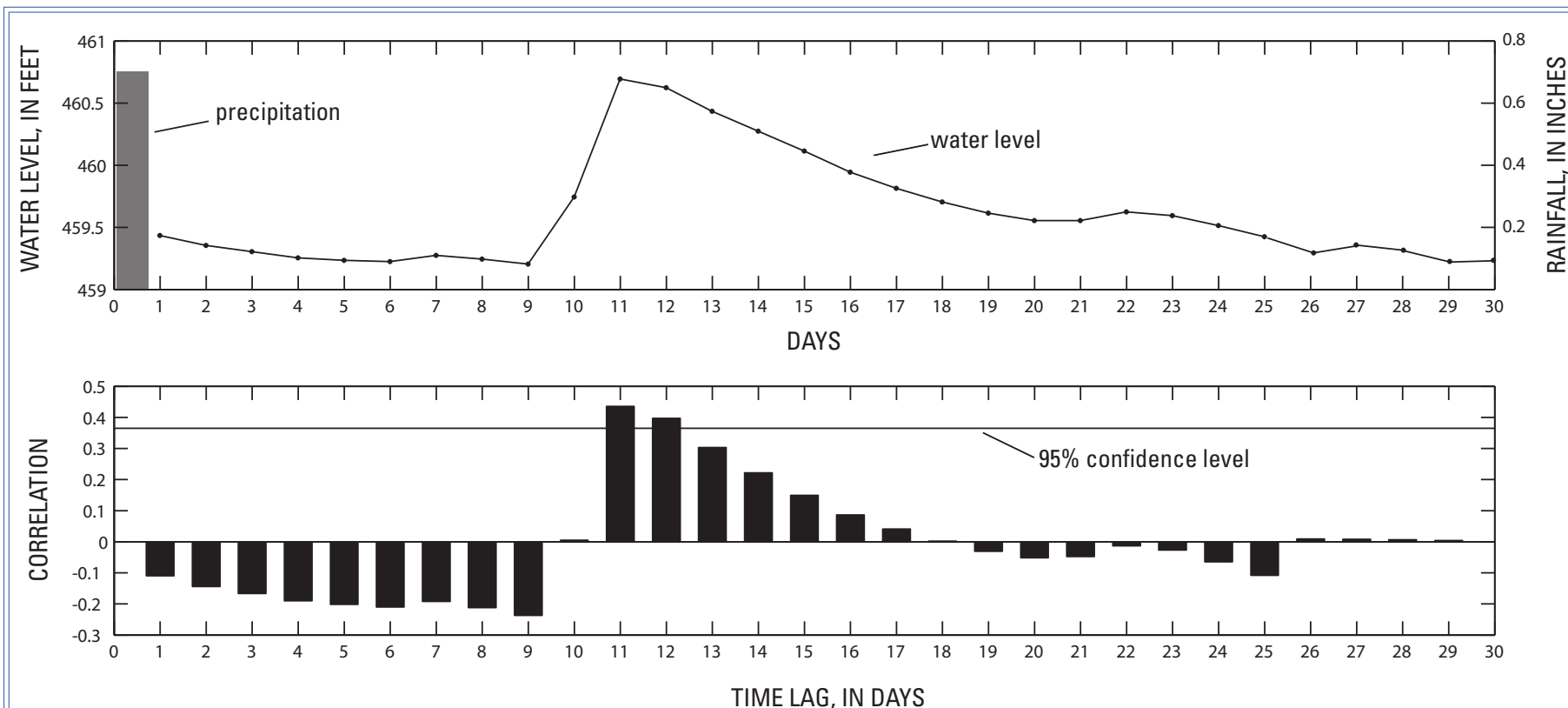

Figure 3. Example cross-correlation plot (bottom) for hypothetical precipitation and water-level time series (top). (Plot modified from Lee and others, 2006.) 
The amount of infiltrating precipitation that moves below the vadose zone and eventually recharges the ground-water system is proportional to the concentration of chloride in bulk precipitation divided by the concentrations of dissolved chloride in ground water. Assuming that surface-water runoff is negligible, annual recharge can be estimated by multiplying this ratio by the average annual precipitation, (Allison and Hughes, 1983).

$$
R=P \frac{C P}{C R}
$$

where, $\quad \mathrm{R}=$ annual recharge, in inches;

$\mathrm{P}=$ annual precipitation, in inches;

$\mathrm{CP}=$ chloride concentration in bulk precipitation, in milligrams per liter;

$\mathrm{CR}=$ chloride concentration in ground water, in milligrams per liter.

\section{Acknowledgments}

The cooperation of private well owners, who permitted measurement of depths to water in their wells, is gratefully acknowledged. The cooperation and assistance of employees of the U.S. Forest Service and the Natural Resources Conservation Service also are gratefully acknowledged.

\section{Precipitation}

In the EMA, climate data have been recorded at the National Oceanic and Atmospheric Administration (NOAA) Sandia Park, New Mexico, weather station (site 9) from 1946 to the present (2008) but data for 2001-07 were used in this report (fig. 1). Site 9 is part of the NOAA National Weather Service (NWS) network that collects climatic information in the United States (National Oceanic and Atmospheric Administration, 2007). Located at an elevation of 7,019 ft near the northern boundary of the study area, site 9 is the only source of long-term continuous climate record within the study area. Additional climate data were collected at three other NOAA NWS weather stations located within $10 \mathrm{mi}$ of Sandia Park that are no longer operational (table 1).

Since 2001, the USGS has collected precipitation data at six climate stations that range in elevation from 6,350$10,030 \mathrm{ft}$ (table 1). This network of stations was designed to define the relation between elevation and precipitation for the Sandia and Manzanita Mountains. Data for 2002, 2004, and 2006 from Sandia Mountain sites 1, 2, 3, and 7 were used for regression analyses (fig. 4). These were the only 3 years for which complete datasets were available. Additional control on the Sandia Mountain elevation-precipitation relation defined by the USGS data was provided by a comparison of 1963-74 data from NOAA sites 8, 9, and 10 (fig. 4). Similarly to the USGS data, the 1963-74 data represent the only common period of complete and continuous data from the three NOAA sites. A regression for the Manzanita sites 5 and 6 was not calculated because of poor constraint provided by data collected from only two locations.

The elevation-precipitation regression equations for the USGS data (eqn. 3), NOAA data (eqn. 4), and two sites in northern New Mexico (Johnson, 1998 (eqn. 5); Pete Stewart, U.S. Forest Service, written commun., 1984 [cited in Wasiolek, 1995] (eqn. 6)) are:

$$
\begin{array}{ll}
y=0.0024(\text { elevation })+0.6923 & \mathrm{R}^{2}=0.17 \\
y=0.0016(\text { elevation })+6.827 & \mathrm{R}^{2}=0.40 \\
y=0.0055(\text { elevation })-27 & \mathrm{R}^{2}=0.82 \\
y=0.0048(\text { elevation })-19 & \mathrm{R}^{2}=\text { unknown }(6)
\end{array}
$$

where,

$$
\begin{aligned}
& \mathrm{y}=\text { annual precipitation, in inches, } \\
& \mathrm{R}^{2}=\text { goodness of fit of the regression line to } \\
& \text { the data, and elevation is in feet. }
\end{aligned}
$$

For all years used in the regression analyses, the parametric one-way analysis of variance (ANOVA) test (Davis, 2002) was used to investigate the significance of the population differences between the USGS and NOAA datasets; both datasets were determined to be normally distributed. ANOVA procedures test the null hypothesis that two populations are drawn from populations having equal variances. The critical value of $\mathrm{F}$ is 2.12 at the 0.05 significance level with $\mathrm{v}_{1}=35$ (NOAA dataset) and $\mathrm{v}_{2}=11$ (USGS dataset) degrees of freedom (Davis, 2002). Because the ANOVA calculated F-value of 0.0015 is less than F-critical, there is no evidence to conclude that the sample populations are different. Despite an annual variability of precipitation exceeding 10 inches for all stations in figure 4, the ANOVA and regression results imply that climate variability over decadal scales in the Sandia Mountains is well defined by the elevation-precipitation relation from the present NOAA and USGS datasets.

Elevation-precipitation regressions from areas of similar topography in northern New Mexico (Wasiolek, 1995; Johnson, 1998) are plotted in figure 4 to provide a comparison to the Sandia Mountains results. The northern New Mexico regressions yield values that fall within the range of most annual values measured in the Sandia Mountains. The influence of topography, however, is more pronounced in the northern New Mexico regressions; regression slopes are a factor of two greater than those in the Sandia Mountains. Annual precipitation is more uniformly distributed across various elevations of the Sandia Mountains as compared to mountains of northern New Mexico that typically receive substantially more winter precipitation at higher elevations. The comparison indicates that the elevation-precipitation regressions are unique to individual mountain ranges and are nontransferable. 


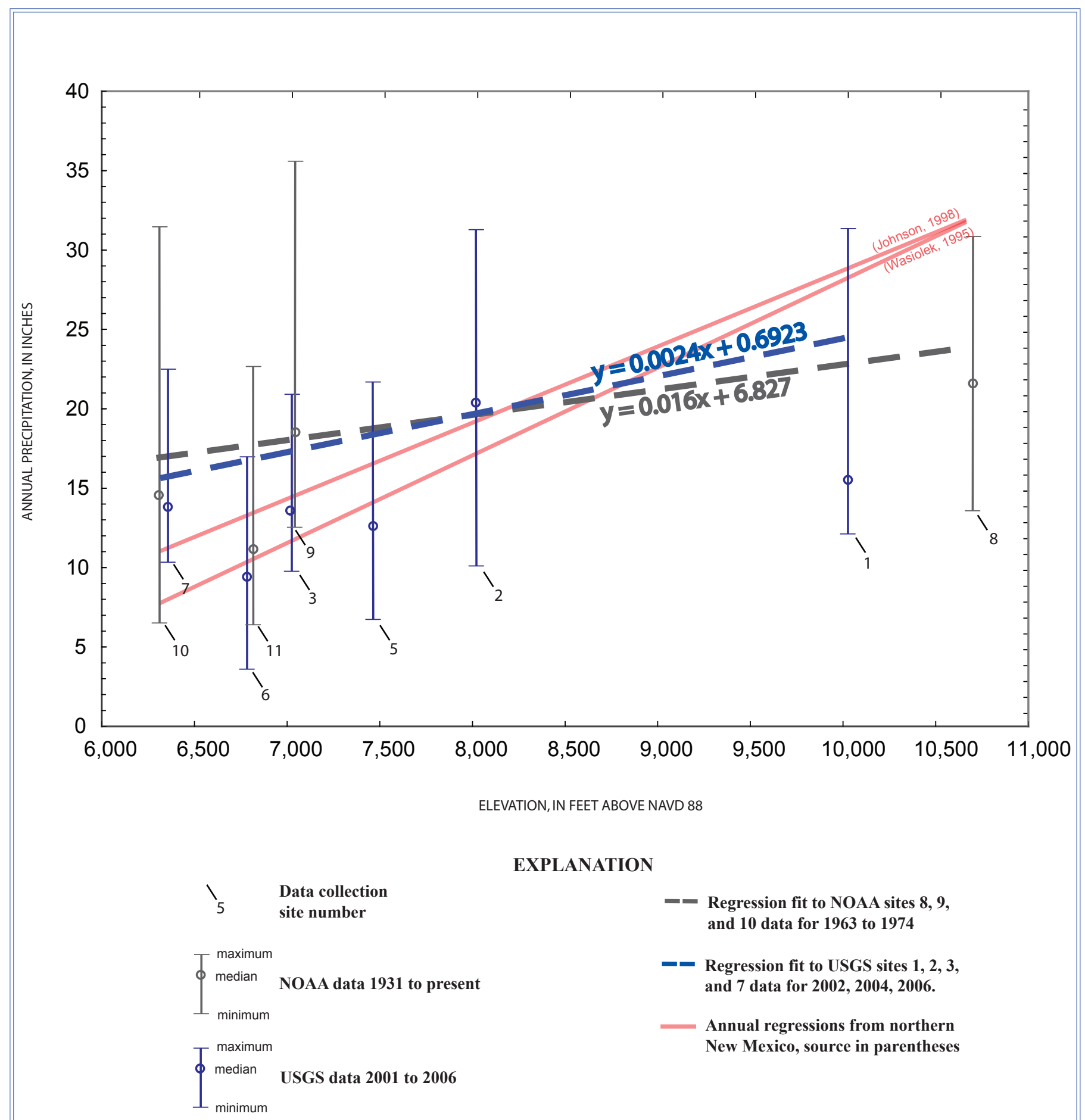


The distribution of monthly precipitation data for sites 8,9 , and 10 for the common period of 1963-74 indicates that about 50 percent of annual precipitation in the Sandia Mountains falls during July through October (fig. 5); close to one-third of annual totals falls during July and August. Mean monthly precipitation is lowest in April, May, and June.

Precipitation totals at site 8 are 66-75 percent and 45-57 percent higher than those at sites 9 and 10, respectively, for the months of December to March. Most of the precipitation at higher elevations during winter months is stored as snowpack until melt periods in early-to-late spring. Snow/ water equivalent (SWE), or the water content of the existing snowpack, is the amount of water that would result from melting of the snowpack. At site $1(10,030 \mathrm{ft}$ above NAVD 88), SWE was measured monthly during the years of 2001, 2004, 2005, and 2007 (table 3). The monthly data show
SWE reaches its maximum during March or April and that snowpack melting is typically complete by late April or early May.

Table 3. Snow-survey data collected by the U.S. Geological Survey at site 1 near Sandia Crest, N. Mex.

\begin{tabular}{llccc}
\multicolumn{5}{c}{ [Abbreviations: SWE, snow water equivalent; --, no data] } \\
\cline { 2 - 5 } \multicolumn{1}{c}{ Month } & $\mathbf{2 0 0 1}$ & $\mathbf{2 0 0 4}$ & $\mathbf{2 0 0 5}$ & $\mathbf{2 0 0 7}$ \\
\hline \hline January & -- & 1.7 & 5 & -- \\
February & 3.8 & 5.9 & -- & 3.7 \\
March & 5.5 & 9.8 & 16 & 4.7 \\
April & 0 & 0 & 22 & -- \\
\hline
\end{tabular}

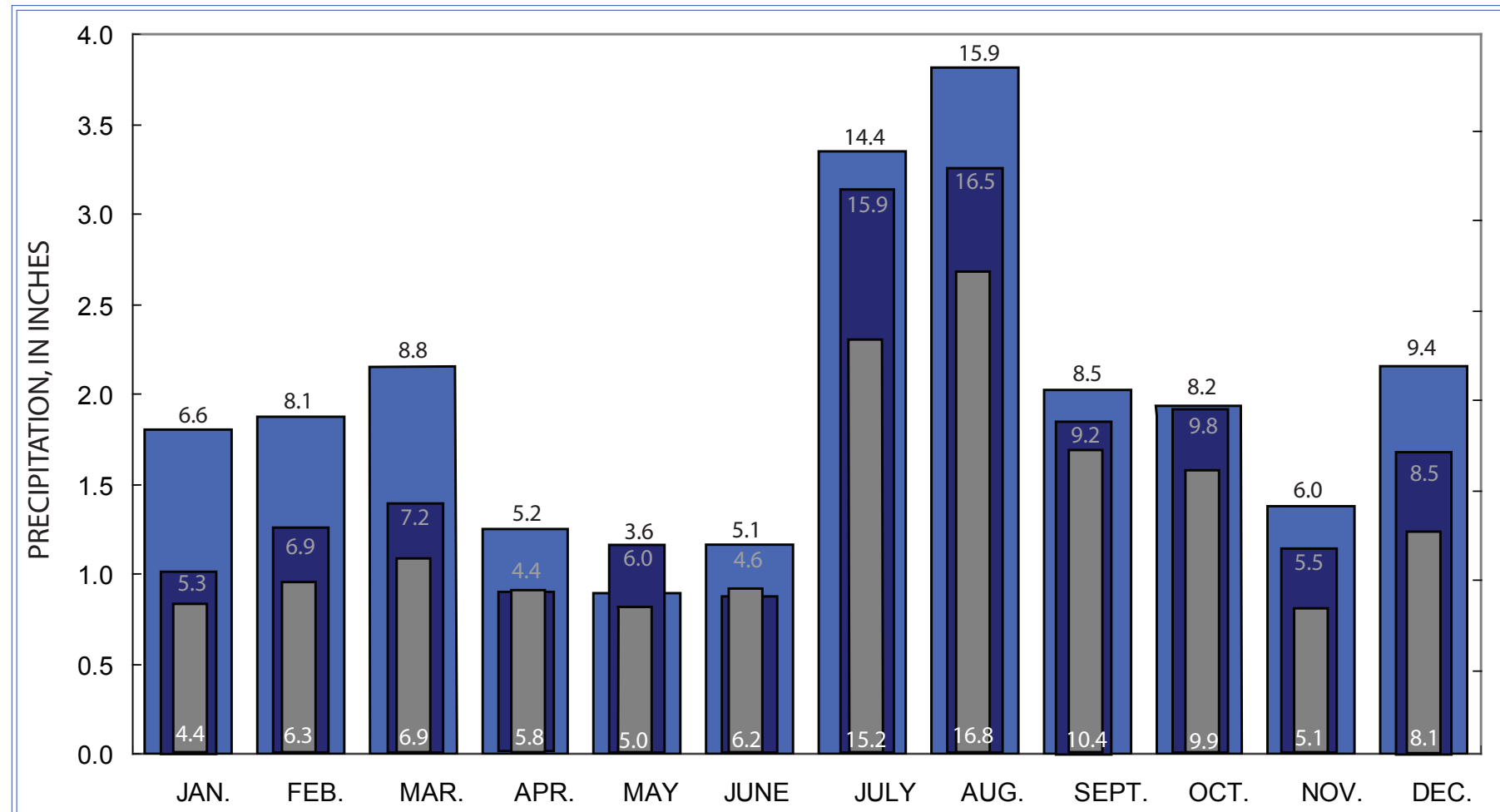

EXPLANATION

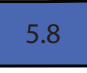

Site 8 and percent of mean annual precipitation values (elevation 10,686 ft)

7.2 Site 9 and percent of mean annual precipitation values (elevation $7,019 \mathrm{ft}$ ) 


\section{Ground-water Hydrology}

\section{Continuous Ground-water Levels}

Daily water-level data from 2005-07 in continuous monitoring wells $12,13,14,15$, and 16 in the EMA are shown in figure 6 with monthly precipitation measured at site 2 , the only site for which continuous precipitation data were available for comparison. The hydrographs indicate that water levels in these wells vary annually from a few tenths of 1 foot to greater than $15 \mathrm{ft}$.

The smallest water-level variability was observed in well 13 , which is presumed a result of its location in a shallow perched aquifer downgradient from the spring at site 46 . The perched aquifer at well 13 is likely continually recharged by spring flow from site 46 . Well 14 was the only well in which water levels appeared to rise, approximately $2 \mathrm{ft}$, without regard to annual climate variability. Response to recharge events may exceed an annual time scale in well 14, which was completed to a depth of $340 \mathrm{ft}$ in the Mesa Verde Group east of the Tijeras Fault. The water-level rise possibly could be influenced by changes in nearby domestic pumping that have not been identified in this study. The influence of the low permeability units of the Mesa Verde Group in the area around well 14 can be seen by a period of recovery exceeding 30 days in May and June 2005 following brief pumping.

Following the 2006 monsoon season in which greater than 7 inches of rainfall were measured at site 2 during both July and August (appendix 1), peaks of amplitude $7.78 \mathrm{ft}$ and $6.14 \mathrm{ft}$ were observed in the hydrographs of wells 12 and 15 , respectively. The peaks were offset by approximately 1 month, with the longer response time observed in well 12 . Well 12 was completed in thinly layered fine to very fine siltstones and sandstones in the upper units of the Dakota sandstone, which may have delayed the timing of water-level response to monsoon rainfall. The open interval of well 15 is shallower (table 2) and overlain by massive mudstones and siltstones of the Chinle Group which may be more transmissive than the thinly layered units of the Dakota sandstone.

Hydrograph response to the winter snowmelt and spring runoff of 2007 was observed in wells 12, 15, and 16. All three of these wells are located west of the Tijeras Fault and are completed in competent formations underlying alluvial material adjacent to arroyos. The respective hydrograph response of wells 12,15 , and 16 associated with the winter snowmelt of 2007 decreases in amplitude with distance from the mountain crest. The largest response to the 2007 snowmelt was observed in well 16, which is completed to a depth of 180 $\mathrm{ft}$ in fine to coarse-grain sediment of the Glorieta Sandstone and Yeso Formation of Permian age.

The absence of flashiness or response to individual precipitation events in the hydrographs of wells 12,15 , and 16 for any of the years of record qualitatively implies either (1) a delayed response to subsurface flow within adjacent hillslopes
(Anderson and Burt, 1978; Burt and others, 2002), or (2) unconsolidated sediment contains large accessible storage to modulate climatic inputs (Florea and Vacher, 2006). For the first case, the rounded peaks are considered a result of an increase in distance, depth, or areal distribution of recharge to the aquifer. In the second case, permeability contrast at the bedrock interface likely provides additional moderation of the downgradient rate of leakage from the overlying alluvial sediment to fractured-rock aquifers. Other factors such as antecedent moisture conditions, hydrogeologic framework of the aquifer, or duration and intensity of seasonal events also may contribute to low amplitude peaks and longer response times to precipitation.

\section{Monthly and Biannual Ground-water Levels}

Ground-water levels were measured monthly in 20 wells from 1990-93 (Kues and Garcia, 1995). In 2002, groundwater level monitoring was resumed on a biannual basis during a period of below-average precipitation (Blanchard, 2004). This network of wells also consisted of 20 wells, 12 of which were selected from the 1990-93 monthly monitoring network of Kues and Garcia (1995). The remaining eight wells in the network had not been previously monitored by the USGS (wells 18, 19, 20 22, 29, 31, 35, and 36).

Biannually measured water levels in 20 wells indicate the depth of water across the study area to range from less than 5 to greater than $200 \mathrm{ft}$ below land surface (figs. 7A-T). Seasonal responses to snowmelt and monsoon periods are noted for most of the sites with monthly data from 1990 to 1993. Similar, qualitative analysis of these hydrographs for that time period is discussed in Kues and Garcia (1995), Rankin (2000), and Blanchard (2004). Several wells within proximity of each other indicate different patterns of waterlevel response to recharge events; wells 30,31,33, and 34 near Sandia Park (fig. 1), for example, are within a 0.4 -mi radius of one another. Discrete water-bearing zones are common in fractured-rock environments that are hydrogeologically controlled by lithologic and structural boundaries (National Research Council, 1996). The hydrograph results near Sandia Park, therefore, are not surprising when the geologic complexity and local-scale pumping of that area are considered.

During a period of below-average precipitation conditions from 2001 to 2003 (Blanchard, 2004) water-level declines of $5 \mathrm{ft}$ to approximately $40 \mathrm{ft}$ were noted in wells $17,18,22,23$, $26,30,31,32$, and 33. A visual analysis of the distribution of wells indicating drought-induced water-level declines did not identify any spatial or geologic patterns in the dataset. Corroborating the results of Blanchard (2004), Kues and Garcia (1995), and Kues (1990), the present dataset indicates ground-water levels in the 67 percent of the wells that indicate drought-induced water-level declines rebounded to near or above predrought levels following the 2005 spring snowmelt; SWE measured during April 2005 was 22 inches near Sandia Crest (table 3). 


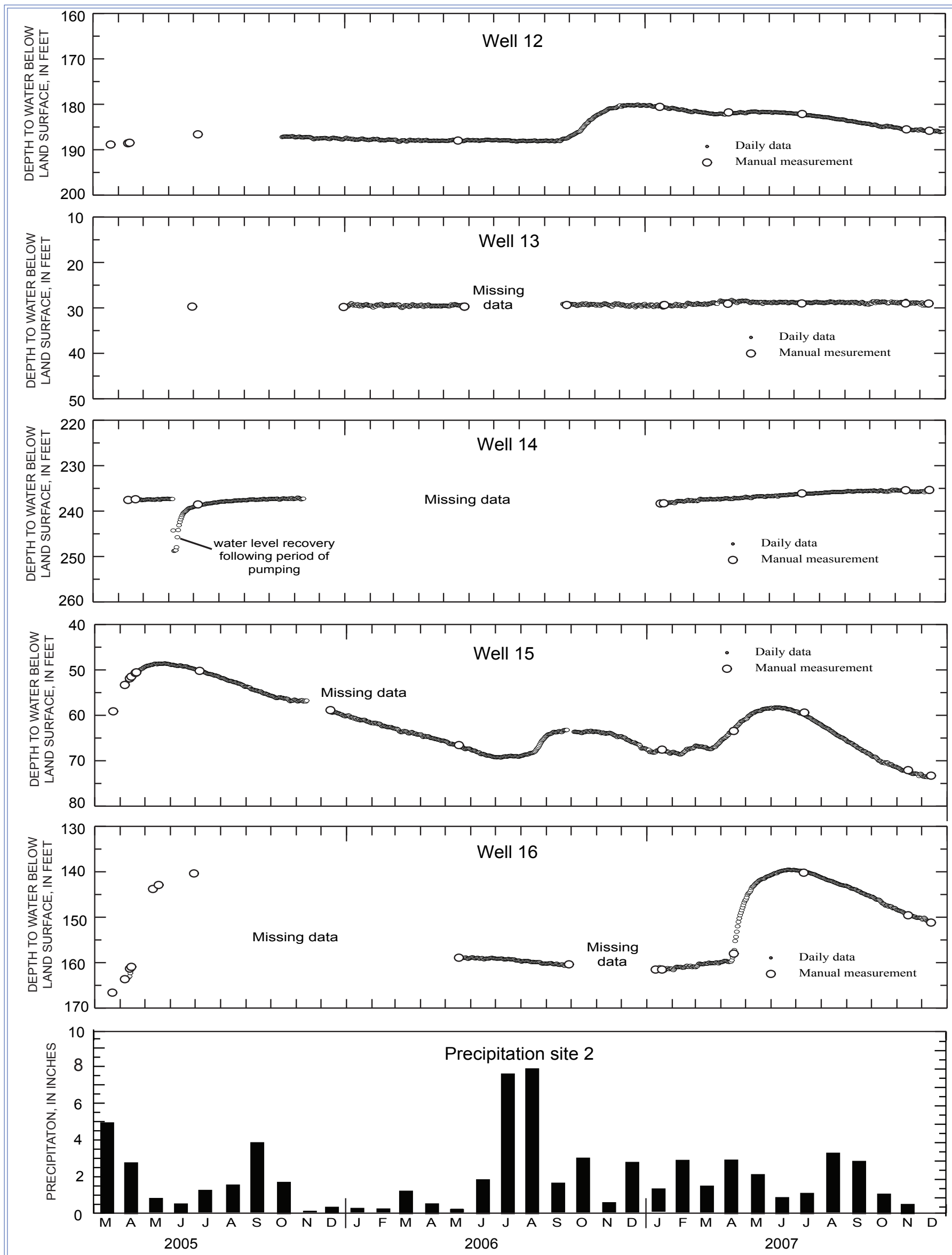

Figure 6. Water-level and precipitation data from continuous monitoring sites in eastern Bernalillo County, N. Mex. 
Precipitation, Ground-water Hydrology, and Recharge Along the Eastern Slopes of the Sandia Mountains

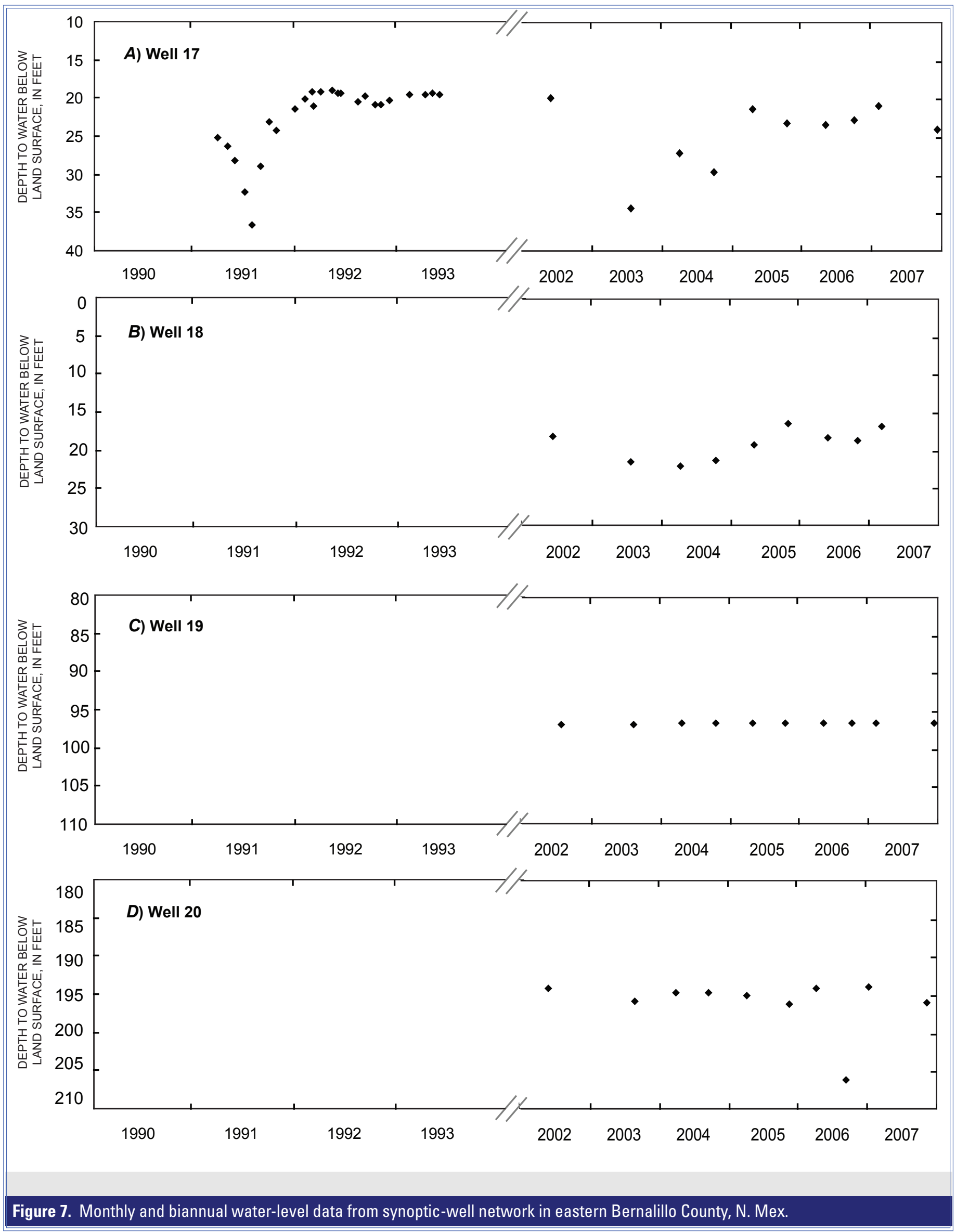




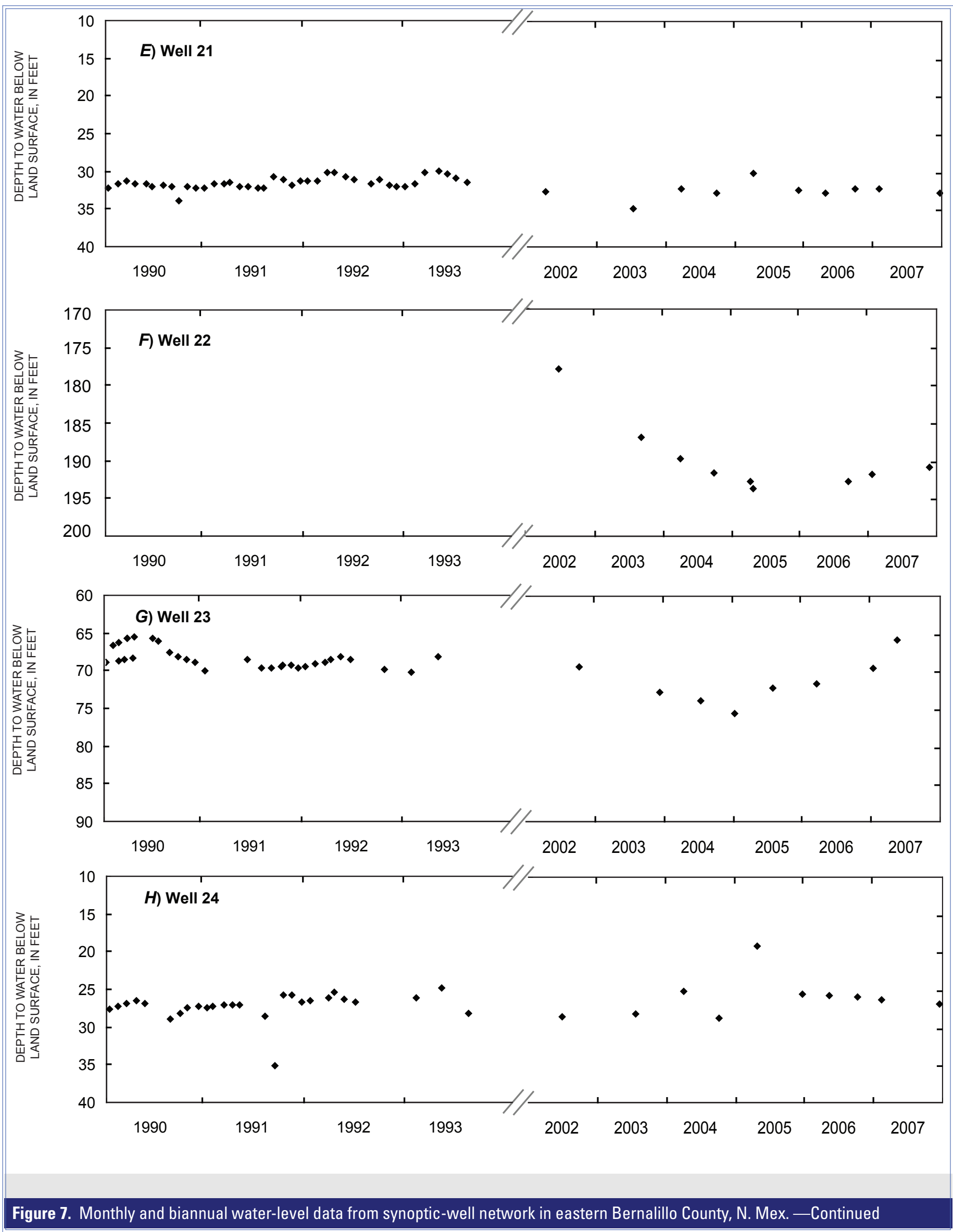




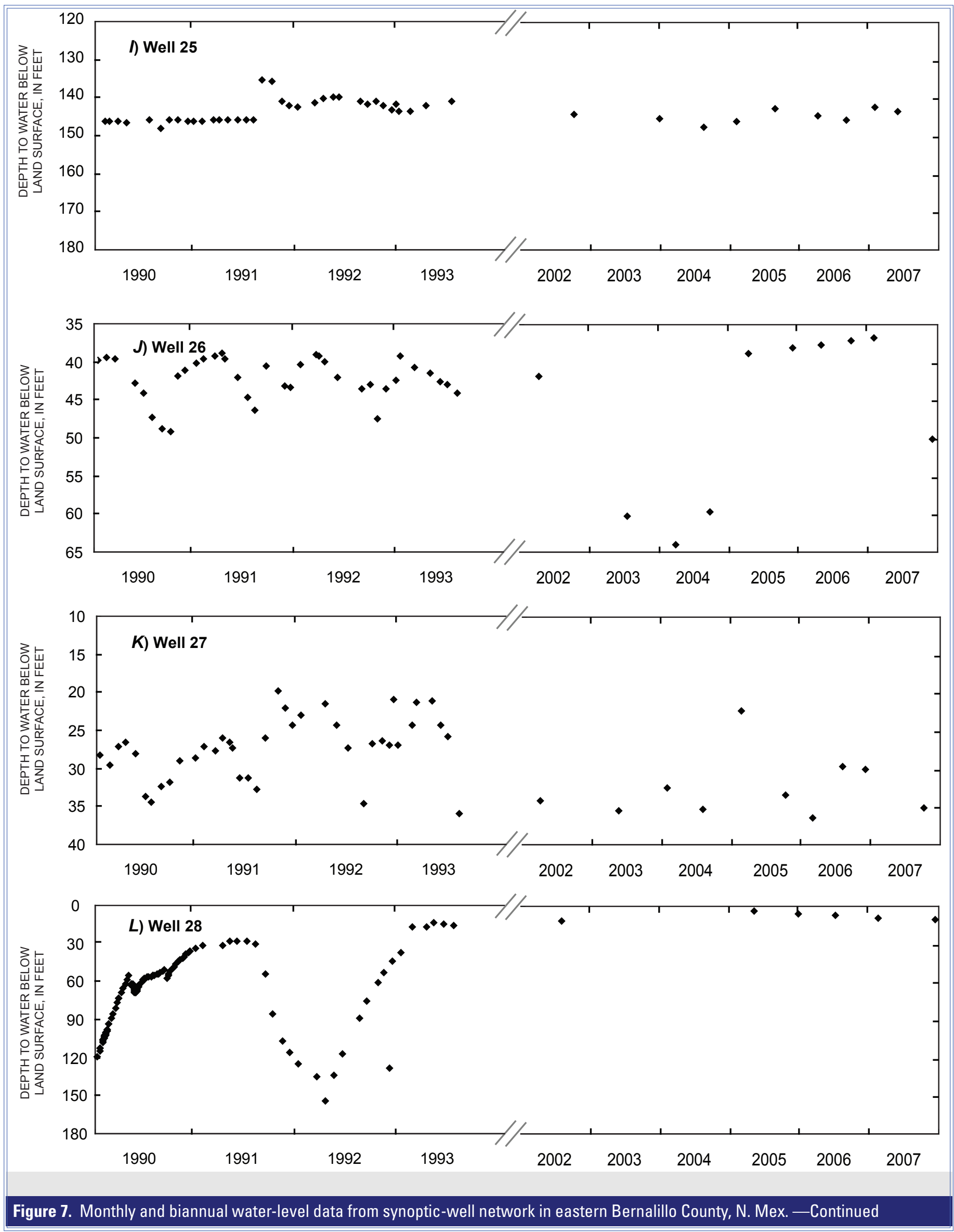




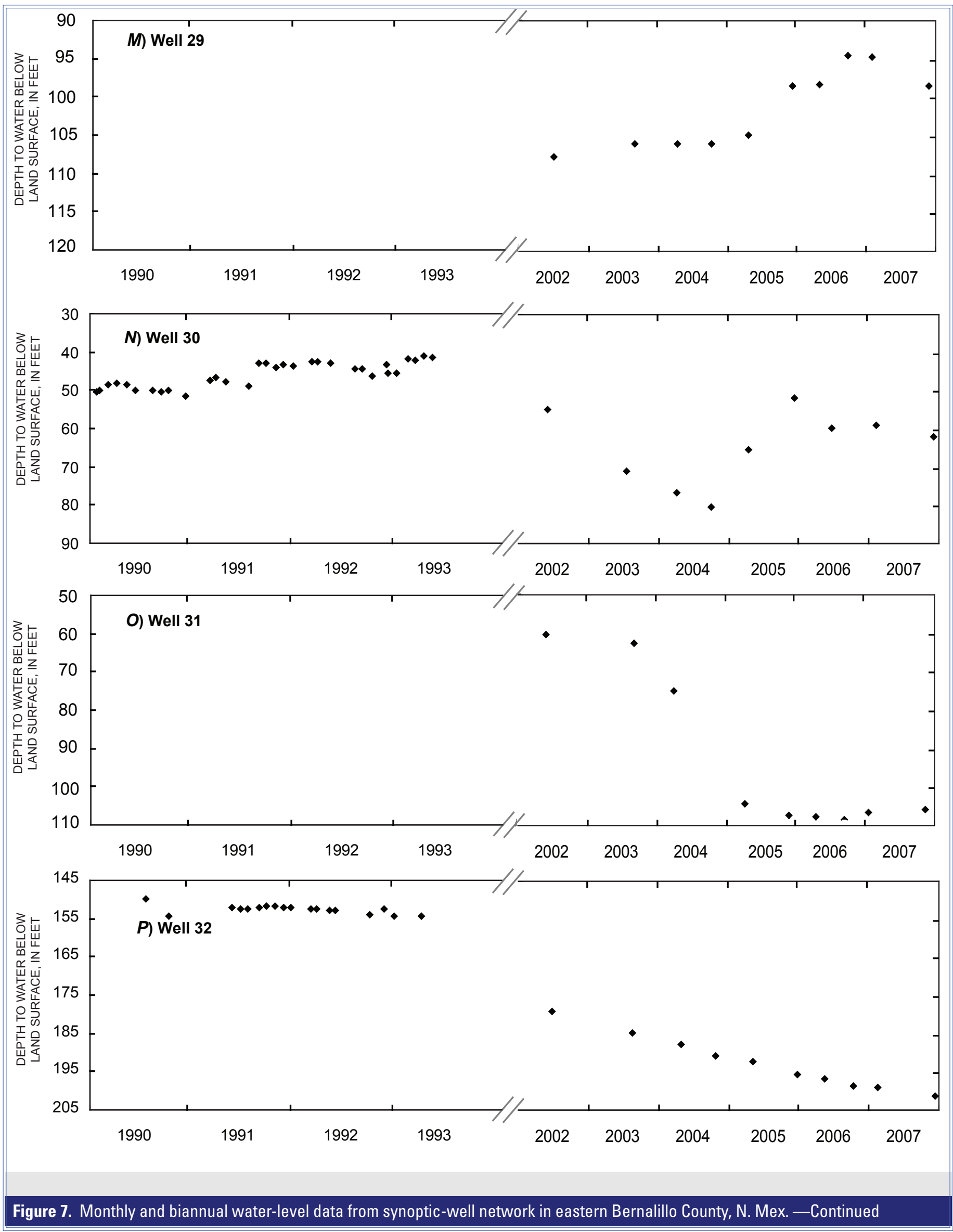




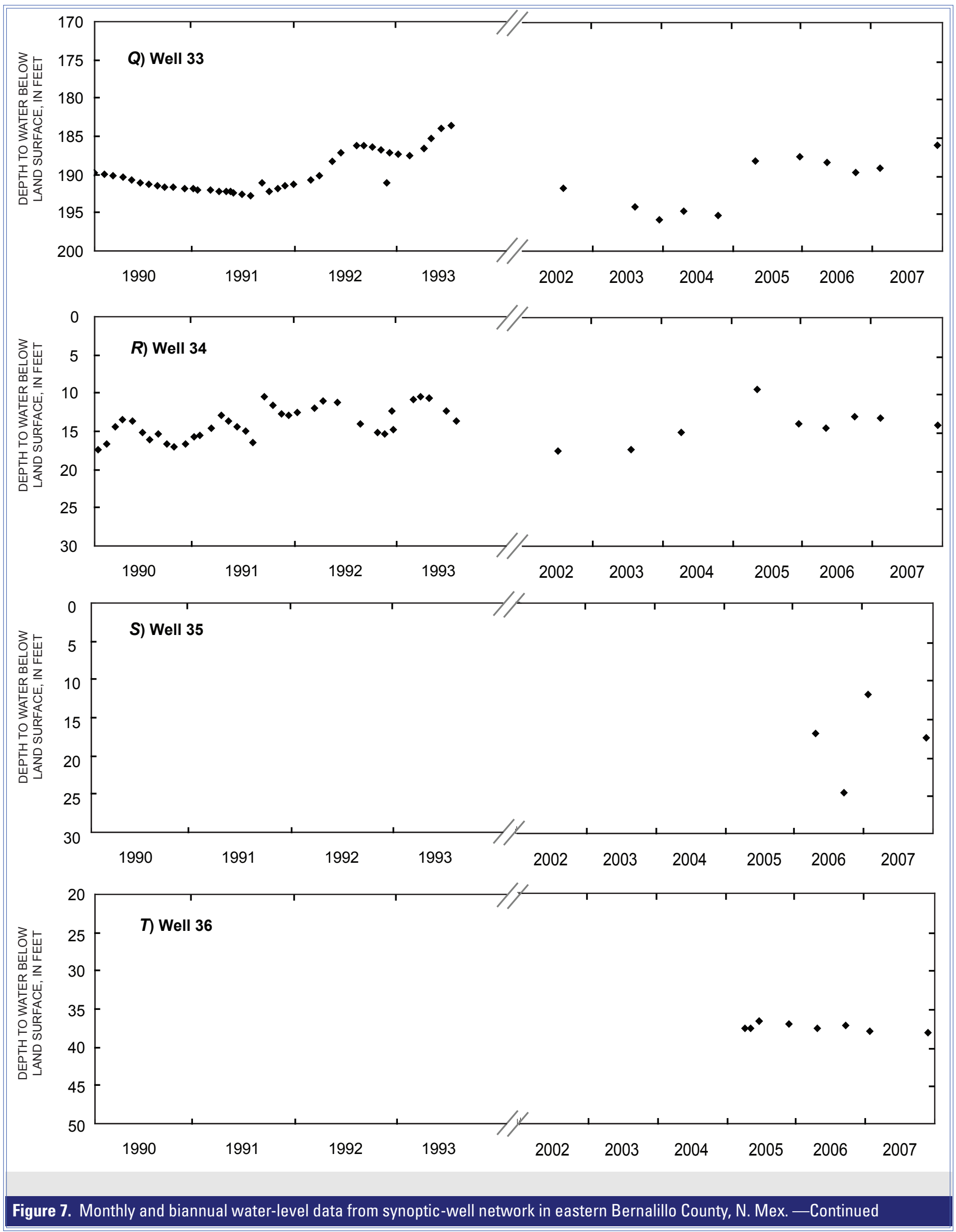




\section{Ground-water Response to Daily Precipitation}

Cross-correlation analyses of precipitation and groundwater levels were conducted by using the 2005-07 daily timeseries data, which were subdivided into sets of continuous data for each calendar year. Subdivisions of a calendar year were chosen to evaluate the response of water levels to annual variability in snowfall and monsoonal rainfall. For annual datasets of daily values from 2005-07, statistically significant correlations were those with $\mathrm{r}_{\mathrm{m}}>0.1047$, the value at which the correlation exceeds the 95 percent confidence interval for a sample size $(\mathrm{N})$ of 365 . Continuous daily data for 2006 are available only for wells 12 and 15 .

A correlogram of precipitation measured at site 2 in 2006 and water levels for the same year in well 12 are shown in figure 8. A long-duration, low-intensity series of rainfall events was recorded during late June through August when summer monsoon rainfall exceeded 0.2 inches on 17 nonconsecutive days. In late September, water levels began to rise and reached peak values in late December.
The correlogram for the 2006 data at well 12 indicates significant and persistent correlation with a lag time of 75-177 days, which corresponds to the approximate 2.5 to 6-month lag observed between monsoonal rainfall and the response in water levels (fig. 8). The peak correlation of 0.3274 occurred at a time lag of 130 days, the approximate time between the rainfall on August 23 and the water level peak on December 26. For well 15, the response time to the monsoonal rainfall was more rapid and of shorter duration. Significant correlations persisted from 58-115 days following the event, and the maximum correlation was at a lag time of 84 days (fig. 9). Prior to the rainfall, water levels in well 15 were declining to minimum values at the time of monsoonal rainfall. Significant negative correlations at a time lag of 0-17 days are ignored as the correlations have no physical meaning and do not reflect a direct relation between rainfall and water levels in well 15.

In January 2007, 105 inches of snowfall were recorded at precipitation site 9 (National Oceanic Atmospheric Administration, 2007). The water levels in all the continuous

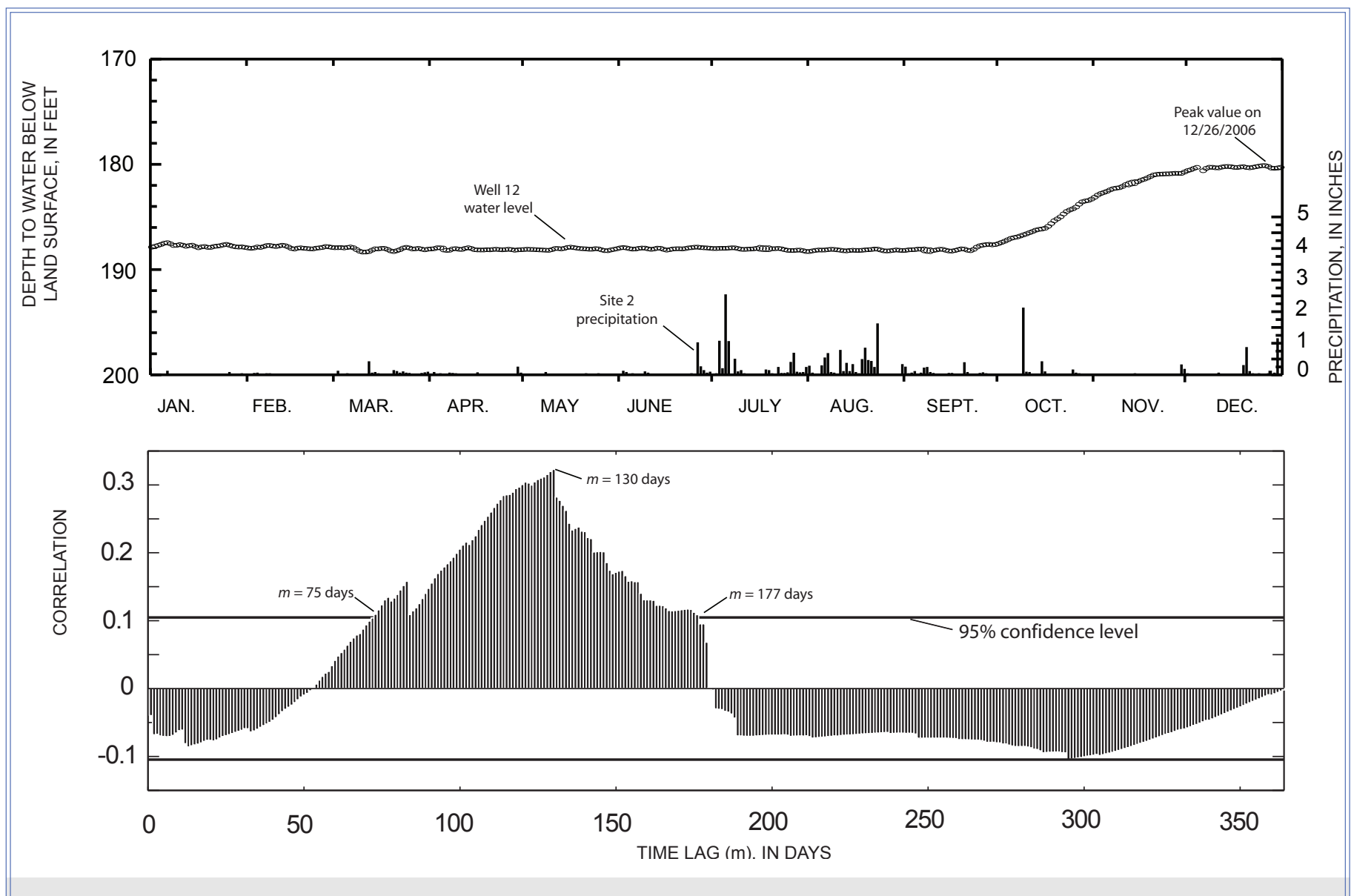

Figure 8. Cross-correlogram between daily precipitation at site 2 and water level at well 12 for 2006 data. 


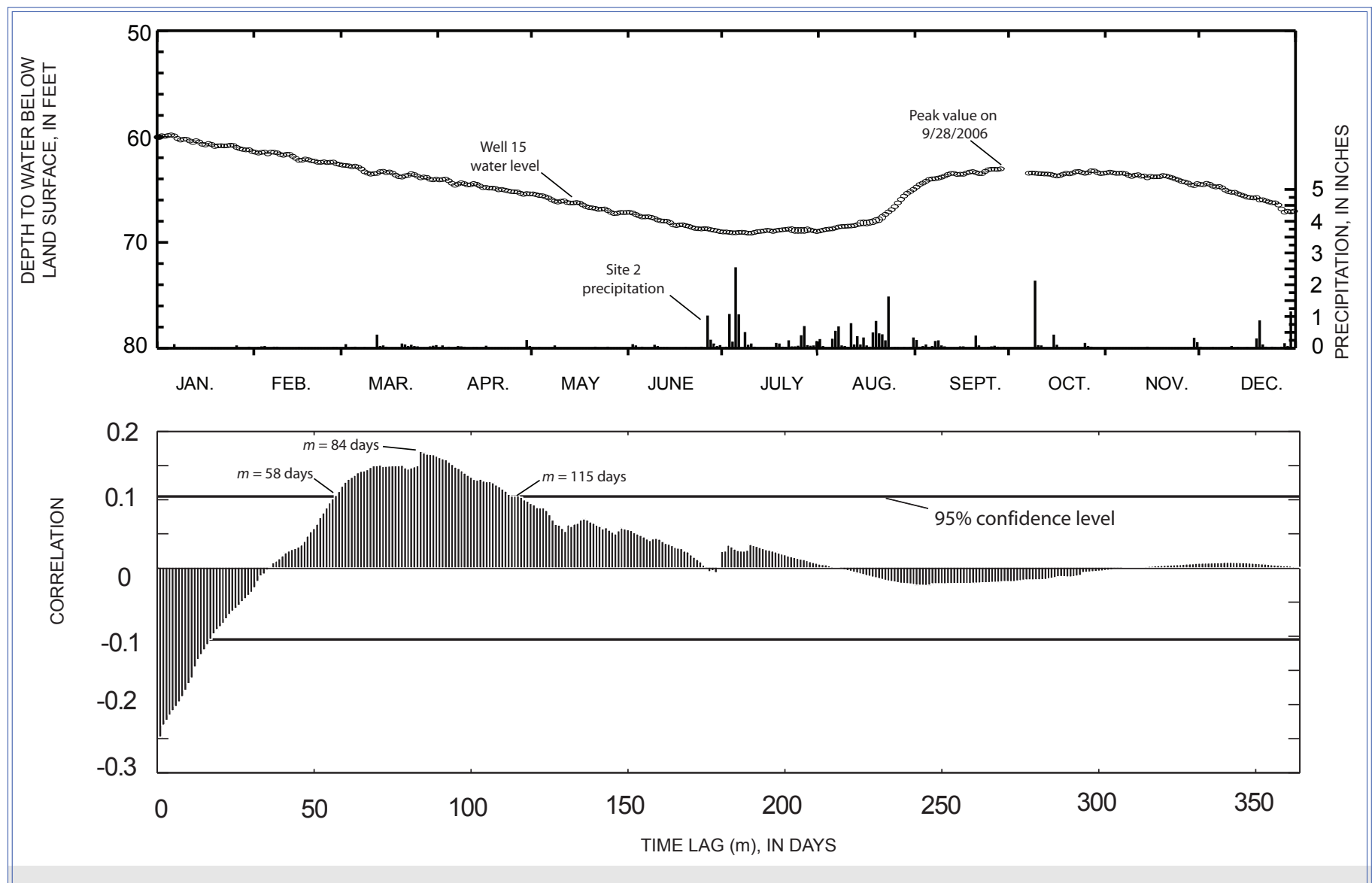

Figure 9. Cross-correlogram between daily precipitation at site 2 and water level at well 15 for 2006 data.

monitoring wells increased during the months of April and May, 2007; however, no statistically significant correlations between daily precipitation and water levels were determined for the data from the five continuous monitoring wells for the year 2007. Although the January 2007 snowfall total ranks only 31 st out of the 55 years of record at Sandia Park, the lack of correlation given the rise in water levels is surprising. These results imply that instantaneous winter precipitation does not directly affect water levels in the aquifer. Data quantifying the storage and subsequent melting of winter snowpack, which are not represented in the current correlation, must be of greater importance to understand the timing of recharge related to winter precipitation than are daily data of snowfall totals. Unlike monsoon events, frozen precipitation in winter months is not immediately available to recharge the aquifer.

Further clarification of processes contributing to waterlevel response following winter snowmelt may be provided by more frequent measurement of snowpack totals, SWE, snowmelt intensity and duration, or soil-moisture content. Such variables can potentially serve as surrogates for the timing of snowmelt events. Because temperature represents another such variable, correlations between water levels and daily average surface temperatures, maximum surface temperatures, and hours above freezing at site 9 may provide additional insight into the timing of recharge following snowmelt. Correlations between any measure of temperature and water levels, however, are beyond the scope of this report and can be misleading if the interpretations are intended to evaluate periods of snowmelt. Daily temperatures in New Mexico peak in late August or early September, too late to be statistically correlated to snowmelt events $4-5$ months earlier in the year.

\section{Ground-water Response to Monthly Precipitation}

Cross-correlation analyses also were conducted on the monthly dataset of water levels, dissolved chloride concentration, and specific conductance collected from 20 wells for the years 1990-92 (Kues and Garcia, 1995). Monthly precipitation data from site 9 (National Oceanic and Atmospheric Administration, 2007) were used for the analyses. Site 9 was the only precipitation station in the area for which data were available during 1990-92 (table 
1). Cross-correlation analyses of precipitation and water levels, chloride, or specific conductance were conducted by subdividing the monthly time series into sets of continuous data for each calendar year. For annual datasets of monthly values, statistically significant correlations were those with $r_{m}>0.5774$, the value at which the correlation exceeds the 95 percent confidence interval for a sample size $(\mathrm{N})$ of 12.

The results of cross correlation for the 1990-92 dataset are shown in table 4. Significant correlations were determined to follow the monsoon season in each of the 3 years of study with lag times that ranged from 1-5 months. Lag-time results were generally consistent when significance was determined for individual wells for multiple years. Similar to the results from the continuous monitoring wells, at no time during this period were water levels, chloride concentrations, or specific conductance statistically correlated with monthly winter precipitation despite a response observed in several wells during spring runoff.

Significant correlations between precipitation and water levels with lag times of 1-3 months were determined for nine of the 20 wells following 7.4 inches of rainfall in July 1991 (fig. 10). All significant correlations with lag times of 1-2 months were limited to wells completed in the Abo-Yeso or Madera Formations, six of which are located south and east of the Gutierrez Fault (wells 21, 25, 27, 37, 40, and 44). The longest lag time of 3 months was found for two wells, one completed in the San Andres Limestone and Glorieta Sandstone of Permian age near Sandia Park (well 42) and the other in alluvium near Carnuel (well 41). Several of the 11 wells with water levels not correlated to the 1991 rainfall had higher water levels following the rainfall possibly indicating either (1) the coarse dataset was unable to capture rapid fluctuations in water levels, or (2) lawns, gardens, and stock

Table 4. Cross-correlation results indicating statistically significant lag times between monthly precipitation and water levels, dissolved chloride, and specific conductance measured in wells of eastern Bernalillo County, N. Mex., 1990 to 1992.

[Site locations shown in fig. 1. Values in parentheses indicate correlation coefficient is negative. Abbreviations: USGS, U.S. Geological Survey; WL, water level; Cl, chloride; SC, specific conductance; --, no correlation.]

Lag time, in months, between precipitation input and water level, chloride, or specific conductance response

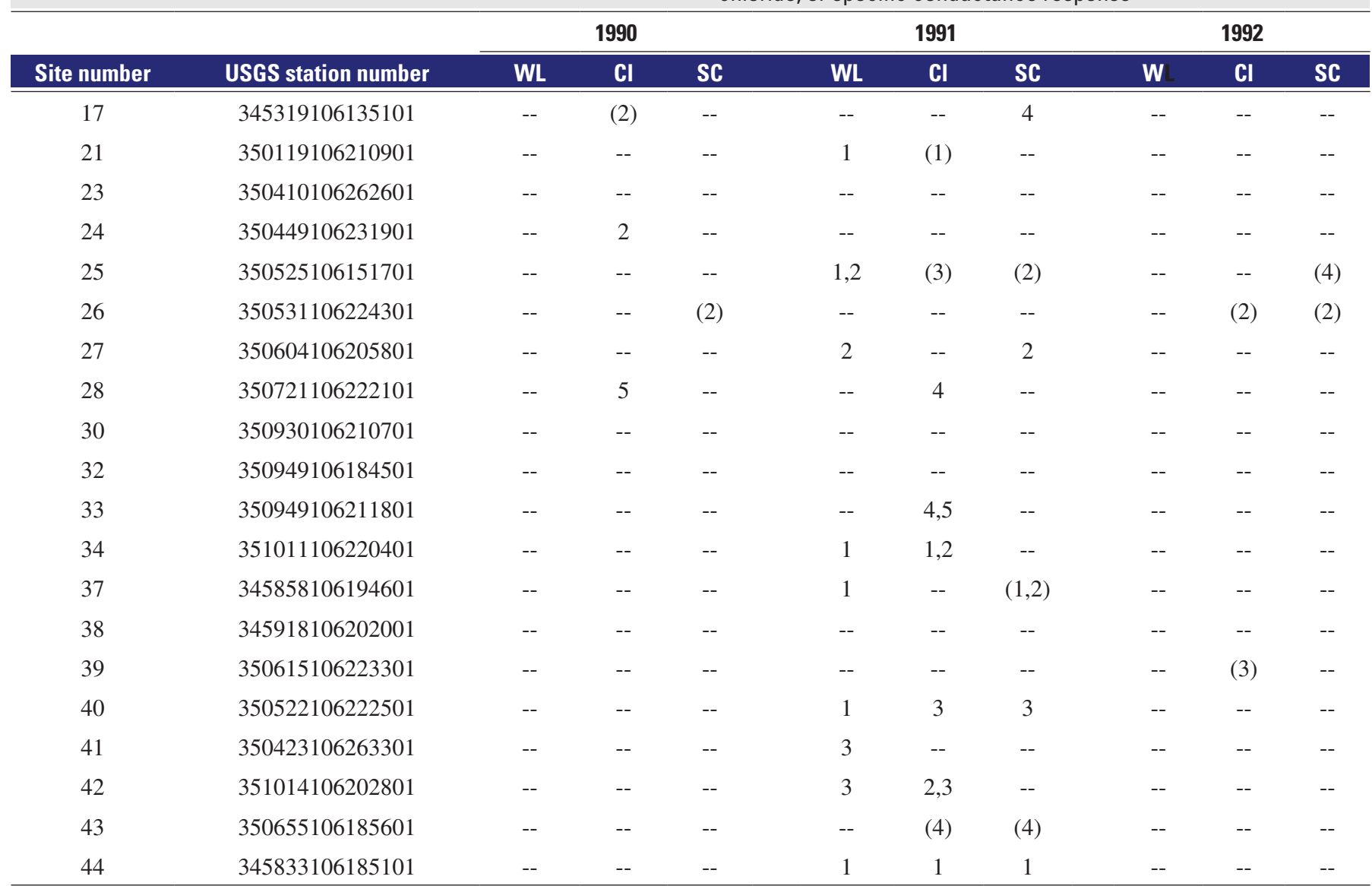




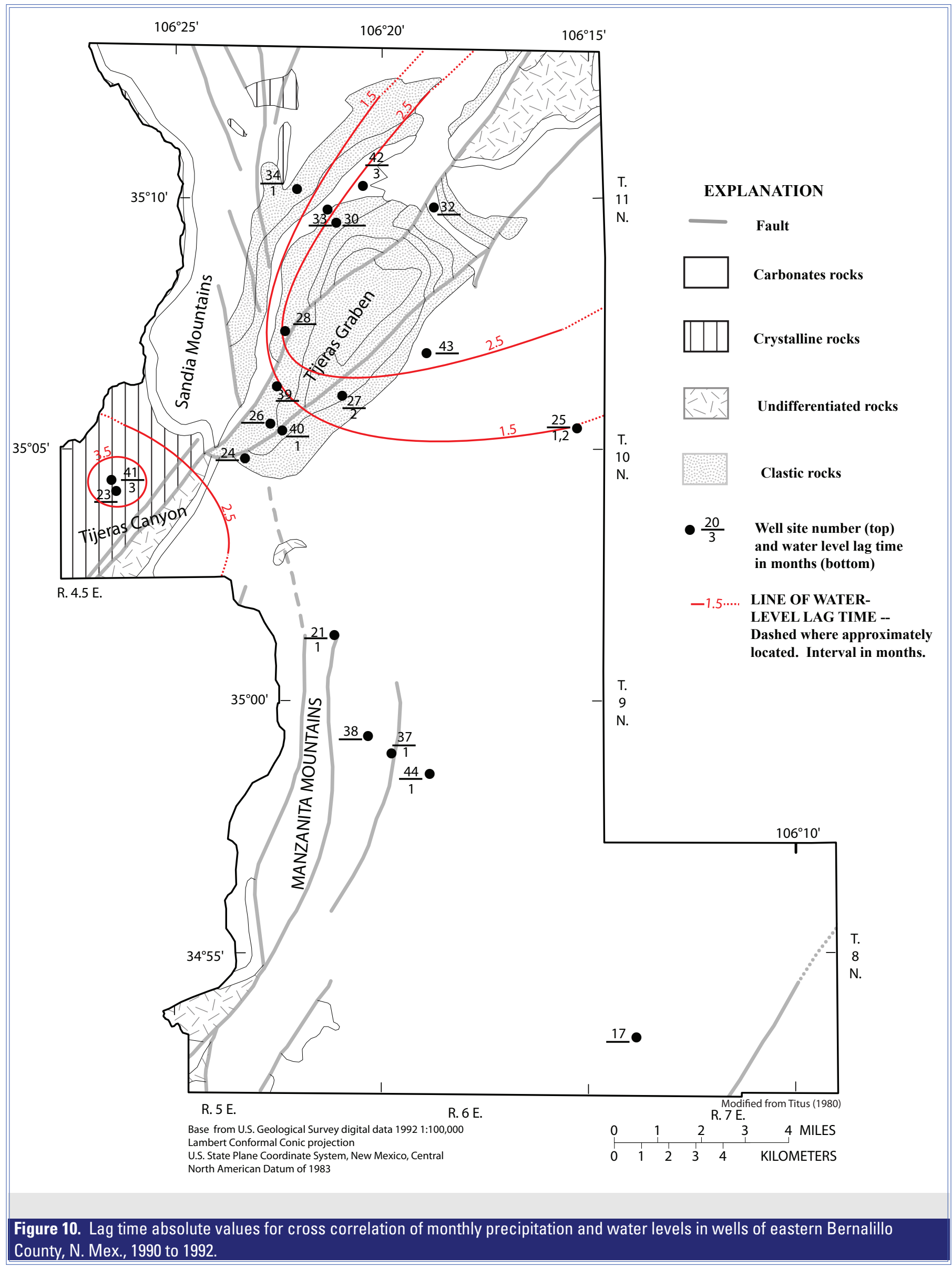


were maintained by lower rates of pumping from the aquifer resulting in uncorrelated water-level rebounds.

For the 3 years of monthly data from 1990 to 1992 , dissolved-chloride concentrations were the most responsive of the tested variables to precipitation. The absolute values of chloride lag times for all years increases in the direction of the low permeability Triassic and Cretaceous geologic units of the Tijeras Graben (fig. 11). Following monsoon rainfall, wells to the north and west of the Tijeras Graben indicate considerable range of lag times (1-5 months) and significant correlations between chloride and precipitation that persist for multiple months (wells 28, 33, 34, 42). These longer duration peaks following monsoon rainfall also generally coincide with the location of the San Andres Limestone outcrop. Negative correlations between rainfall and chloride concentration or specific conductance (fig. 12) are spatially limited to areas south and east of the Tijeras and Gutierrez Faults. Negative correlations are consistent with the shortest water level lag times (fig. 11) and represent the introduction of dilute or perhaps recently recharged water to the aquifer. Rapid influx can be expected where discrete lithologic or structural discontinuities intersect flowing arroyos. Positive correlations north of the Tijeras Fault may represent either solute flushing or piston-flow mechanisms mobilizing ground water from storage.

Cross-correlation results from wells 23, 30, 32, and 38 (table 4) indicate no significant correlation between precipitation and water levels, chloride concentrations, or specific conductance for any of the years of study. These wells are located along upland slopes or topographic highs near local drainage-basin boundaries. The absence of significant correlation from well 23 data is surprising because of its location in the thick alluvium near Carnuel, New Mexico. Variability in the well 23 hydrograph (fig. $7 \mathrm{~g}$ ) and the response to individual precipitation events may be tempered by high transmissivity and storativity common to alluvial aquifers (Fetter, 1988). Biannual measurements since 2002 at wells 30 and 32 show water levels have declined in comparison to the 1990-93 dataset (fig. 7n and $7 \mathrm{p}$ ). A response to drought conditions is observed in the hydrograph of well 30 although water-level rebound does not reach predrought levels. Water levels in well 32 appear to be isolated from the influence of precipitation; the constant rate of decline, however, indicates depletion of ground water in storage near this well.

The observed correlations for the monsoon rainfall in 1991 and 2006 are an indication that both (1) short-duration, high-intensity and (2) long-duration, low-intensity summer rainfall produce physical and chemical responses in wells that reveal the importance of monsoon rainfall to recharge aquifers along the eastern slopes of the Sandia Mountains. These were the only 2 years of the investigation in which rainfall exceeded 7 inches for a single month during monsoon season. In areas north and west of the Tijeras Fault, the long duration of aquifer water-level response to monsoon rainfall of both years indicates that the pathway for recharging water may be slow through a low-permeability diffuse fracture network potentially receiving leakage from overlying alluvial aquifers. Additionally, steeply dipping bedding planes north and west of the Tijeras Fault are orthogonally oriented to regional flow directions, and they may serve as low-permeable barriers to downgradient flow. The lag times shown in figure 11 also indicate that carbonate units such as the San Andres Limestone may preferentially direct flow laterally along bedding.

Water-level or geochemical response of aquifers in the Tijeras Graben to precipitation events is limited to wells 26 and 39 (fig. 1). These two wells are located near the southwestern terminus of the Tijeras Graben, the point of intersection of the Tijeras and Gutierrez Faults, an area presumed to have undergone extensive deformation. Wells 14 and 32 (fig. 1), located farther north and east of wells 26 and 39 in the Tijeras Graben at greater distance from the deformation front, show water-level trends absent of any visual or statistical correlation with annual precipitation.

South and east of the Gutierrez Fault, water levels, chloride, and specific conductance results indicate that the aquifer response to rainfall is relatively quick and of short duration. This type of flashy response is common in fractured-rock aquifers with small storage coefficients or a predominance of fractures oriented in the direction of flow. Regardless, all the results from the 1990-92 data indicate areas separated by the Tijeras and Gutierrez Faults are unique hydrostructural domains. These conclusions corroborate previous conceptualizations of the role of the Tijeras Fault to serve as a hydrologic barrier to ground-water flow moving eastward from the Sandia Mountains (Titus, 1980; Kues, 1990).

\section{Recharge Estimates and Chloride Trends}

Water-quality samples were collected from spring sites 45-49 (fig. 1) from March 2005 to December 2007 and analyzed for dissolved-chloride concentration (fig. 13). Chloride concentrations in samples collected from Carlito, Canocito, and Cole Springs were similar, ranging from 1.61$1.94 \mathrm{mg} / \mathrm{L}, 1.88-2.29 \mathrm{mg} / \mathrm{L}$, and $1.31-1.73 \mathrm{mg} / \mathrm{L}$, respectively. Concentrations of chloride in samples collected from Cienega and Wolf Springs varied widely and ranged from 2.43-20.70 $\mathrm{mg} / \mathrm{L}$ and 4.33-41.50 mg/L, respectively. At each of the five springs chloride concentrations increased following a 3-month period from January through March 2005 when a total 10.16 inches of precipitation was recorded at site 3 (fig. 13). The increase in chloride concentrations following an unusually wet period indicates that either (1) chloride had been accumulating in the vadose zone during the preceding dry years of 2001-03 or (2) piston-flow mechanisms have mobilized and displaced ground water in storage that may have dissolved chloride originating from marine sediments. In flow systems with a large amount of storage and relatively long flow paths, 


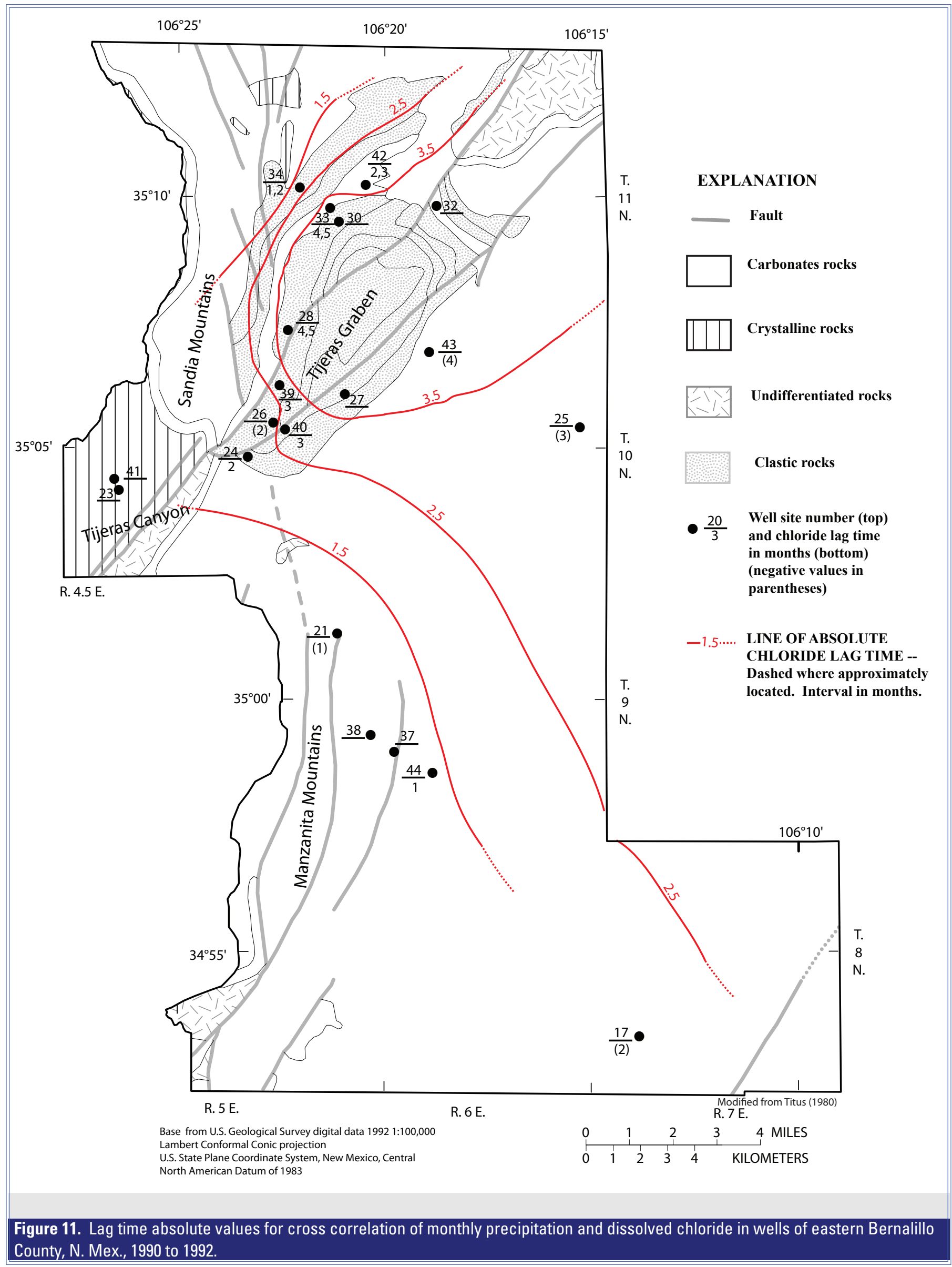




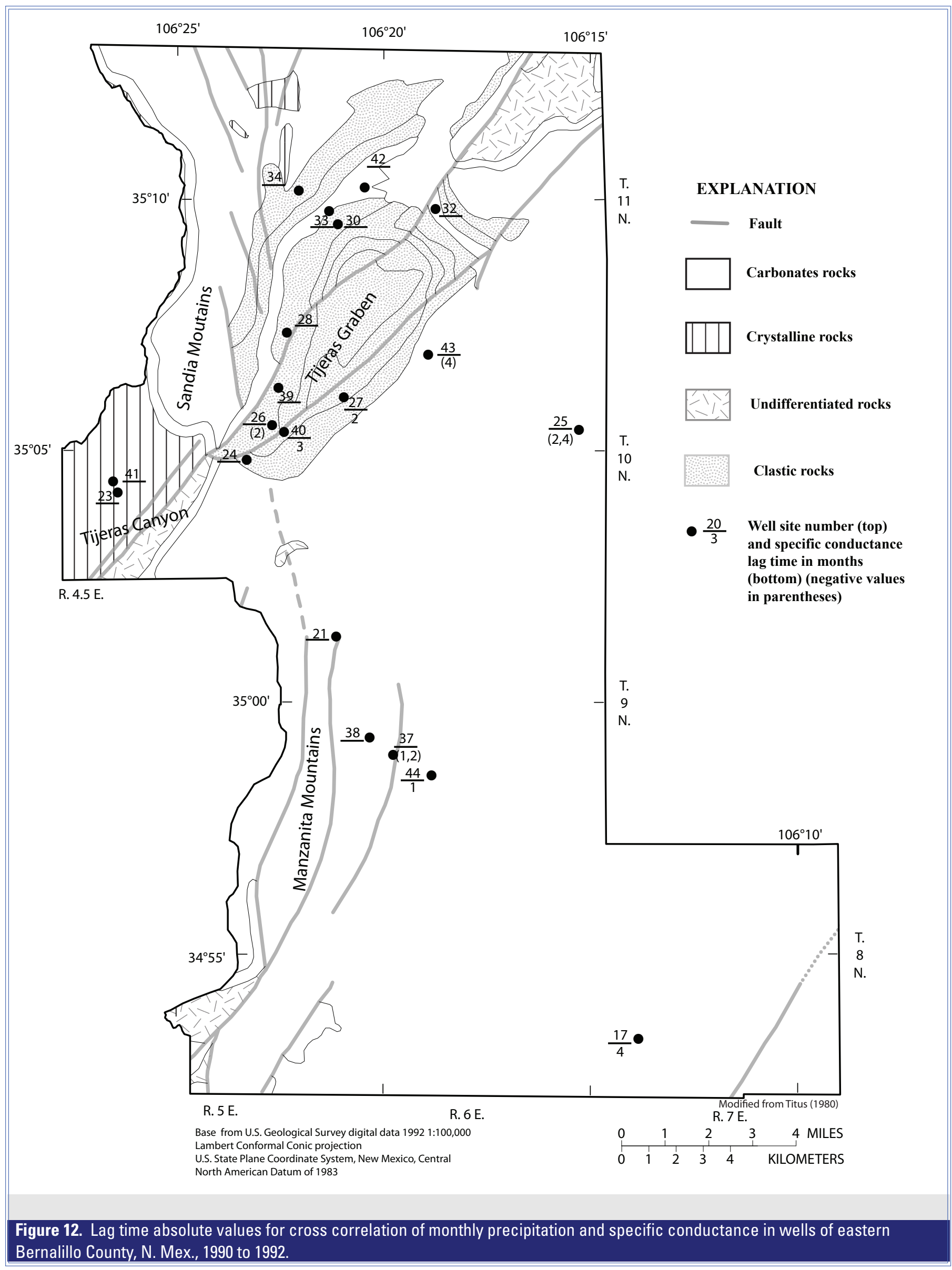


chloride concentrations would not be expected to vary as much as in aquifers with little storage and short flow paths where mixing volumes and times would be less. Concentrations in all springs decline for more than 12 months following peak values and indicate extended periods of solute flushing following precipitation. No data are available to evaluate whether extended periods of decline in chloride concentration of springs are related to discharge.

Two assumptions are required prior to calculating recharge by using equation 2 . First, all dissolved chloride in ground water discharging at the springs was assumed to be from precipitation. Second, equation 3 can be used to calculate the average annual precipitation $(\mathrm{P})$ between 7,500 $\mathrm{ft}$ and $10,500 \mathrm{ft}$, or the approximate range in elevation of the recharge area for four of the five springs. Given these assumptions, a calculated value of $P$ equal to 22 inches, and the chloride concentration in bulk precipitation $(\mathrm{CP})$ near the
Sandia Mountains of $0.30 \mathrm{mg} / \mathrm{L}$ (Anderholm, 2000) were used in chloride-mass-balance calculations (equation 2).

Median annual recharge determined by using the median chloride concentration in samples from Carlito, Canocito, and Cole Springs was 3.9, 4.2, and 3.2 inches, respectively (table 5). Using the median chloride concentration in samples from Cienega and Wolf Springs, median annual recharge was estimated to be 0.4 and 0.2 inches, respectively. Estimated recharge rates for all springs ranged from $0.70-23$ percent of mean annual precipitation (percent recharge) above 7,500 ft in the Sandia Mountains and were similar to the range of 0.70-21 percent recharge determined by Anderholm (2000) for aquifers along the eastern side of the middle Rio Grande basin.

The area of the Madera Formation above 7,500 ft elevation in the Sandia Mountains and exposed to the south and east of Sandia Crest is about $13 \mathrm{mi}^{2}$ (fig. 2). Assuming the mean annual precipitation of that area is about 22 inches and recharge ranges from $0.70-23$ percent of annual precipitation,

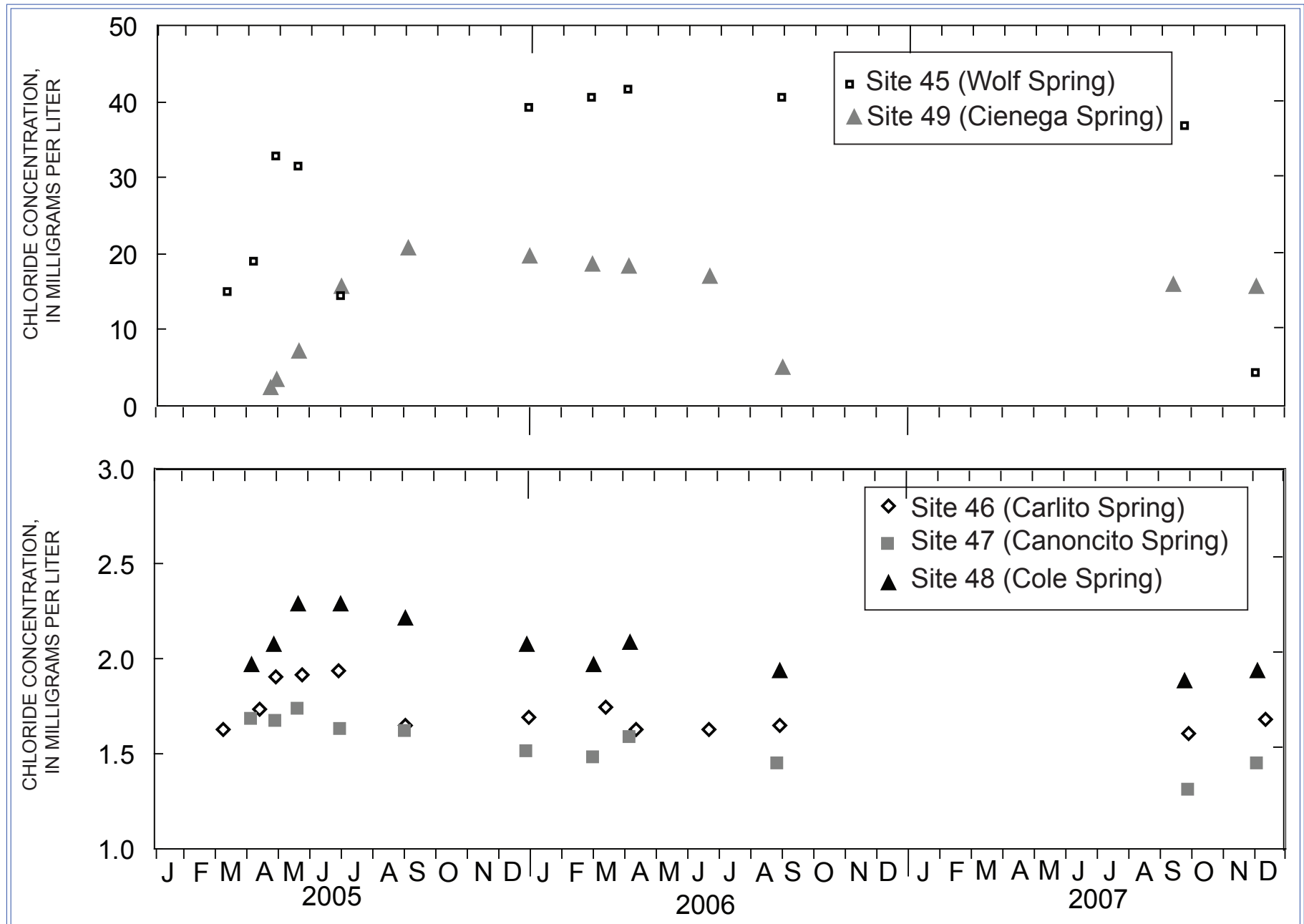

Figure 13. Dissolved-chloride concentration in spring water samples collected from eastern Bernalillo County, N. Mex. Sites shown in figure 1. 
Table 5. Median, minimum, maximum, and range of percent recharge at selected springs estimated by using the chloride mass balance technique.

[Site locations shown in fig. 1. Abbreviations: mg/L, milligram per liter; in, inches]

\begin{tabular}{|c|c|c|c|c|c|c|c|c|c|}
\hline \multirow[b]{2}{*}{$\begin{array}{c}\text { Site } \\
\text { number }\end{array}$} & \multirow[b]{2}{*}{ Spring name } & \multirow[b]{2}{*}{$\begin{array}{c}\text { Number } \\
\text { of samples }\end{array}$} & \multicolumn{3}{|c|}{ Chloride concentration (mg/L) } & \multicolumn{3}{|c|}{ Estimated annual recharge (in) } & \multirow[b]{2}{*}{$\begin{array}{l}\text { Percent recharge } \\
\text { range (percent) }\end{array}$} \\
\hline & & & Median & Minimum & Maximum & Median & Minimum & Maximum & \\
\hline 46 & Carlito & 13 & 1.69 & 1.61 & 1.94 & 3.9 & 3.4 & 4.1 & $15-19$ \\
\hline 47 & Canoncito & 11 & 1.59 & 1.31 & 1.73 & 4.2 & 3.8 & 5.0 & $17-23$ \\
\hline 49 & Cienega & 12 & 15.9 & 2.43 & 20.7 & 0.4 & 0.3 & 2.7 & $1.4-12$ \\
\hline
\end{tabular}

the estimated mean annual recharge to the Madera Formation above 7,500 ft ranges from 1,000-3,500 acre-feet per year.

Heterogeneous recharge patterns on a basin scale are implied by larger chloride concentrations and smaller recharge estimates from Cienega and Wolf Springs than from those in the other three springs. Carlito, Canoncito, and Cole Springs are located along fault zones that may prohibit downgradient flow, and instead focus discharge from large areas upgradient from the springs to these unique locations. Faults intersecting areas upgradient from Cienega and Wolf Springs may divert ground water moving downgradient in those drainages, effectively limiting the amount of recharge from high elevations reaching those springs.

\section{Summary and Conclusions}

In eastern Bernalillo County, New Mexico, most of the annual precipitation occurs as snowfall from January through March and as monsoonal rainfall from July through August. Cross-correlation analyses were conducted between precipitation and water levels, chloride concentrations, and specific conductance data collected during the years of 1990-92 and 2006-07 to evaluate aquifer response to recharge from seasonal precipitation events.

Recharge following monsoon rainfall reaches aquifers along the eastern slopes of the Sandia Mountains 1-5 months following an event. Aquifer water-level response to monsoon rainfall was limited to years when monthly rainfall totals for July or August were more than 7 inches at Sandia Park. During both episodic and long-duration monsoon rainfall, aquifer response is shown to persist for 1-5 months following events. Persistence of aquifer response to storm events exceeding 1 month was limited to areas north and west of the Tijeras Fault. In these areas, long lag times and persistent statistical significance of water-level, chloride, and specific- conductance responses to monsoonal rainfall events indicate that the orientation of bedding may limit the velocity of ground water following regional flow gradients.

Lag time response generally increased in the direction of the Tijeras Graben, an area having three of five wells near topographic divides that indicated no chemical or hydrologic response to annual monsoon events. These wells are considered isolated from input from individual precipitation events and are located in areas where ground-water depletion could be a concern.

Instantaneous winter precipitation was not statistically correlated to water-level fluctuations for any of the years of study. Rising water-levels following spring runoff observed in many of the hydrographs indicates that other mechanisms such as snowmelt intensity and duration, soil moisture, or hydrologic properties of the aquifer may be more important than instantaneous precipitation to understanding the role of winter snowpack to recharge the aquifer.

Recharge to springs along the eastern slopes of the Sandia Mountains estimated from chloride mass-balance calculations ranges from 1-23 percent of annual precipitation. The variability in recharge amounts is considered a result of structural heterogeneities diverting flow from high-elevation recharge locations towards unique points along fault zones. These heterogeneities may actually decrease the amount of ground water discharged at springs located in topographically downgradient areas.

\section{References Cited}

Allen, B., 2003, Preliminary geology of the Chilili 7.5-minute quadrangle, Bernalillo and Torrence Counties, New Mexico: New Mexico Bureau of Geology and Mineral Resources Open-file Geologic Map OF-GM 81, scale 1:24,000. 
Allen, B.D., 2002, Preliminary geologic map of the Escabosa 7.5-minute quadrangle, Bernalillo County, New Mexico: New Mexico Bureau of Geology and Mineral Resources Open-file Geologic Map OF-GM 49, scale 1:24,000.

Allison, G.B., and Hughes, M.W., 1983, The use of natural traces as indicator of soil-water movement in a temperate semi-arid region: Journal of Hydrology, v. 76, p. 1-25.

Anderholm, S.K., 2000, Mountain-front recharge along the eastern side of the middle Rio Grande basin, central New Mexico: U.S. Geological Survey Water-Resources Investigations Report 00-4010, 36 p.

Anderholm, S.K., 1994, Ground-water recharge near Santa Fe, north-central New Mexico: U.S. Geological Survey WaterResources Investigations Report 94-4078, 68 p.

Anderson, M.G., and Burt, T.P., 1978, The role of topography in controlling throughflow generation: Earth Surface Processes, v. 3, p. 331-344.

Blanchard, Paul J., 2004, Precipitation; ground-water age; ground-water nitrate concentrations, 1995-2002; and ground-water levels, 2002-03 in Eastern Bernalillo County, New Mexico: U.S. Geological Survey Scientific Investigations Report 2004-5189, 36 p.

Blanchard, Paul J., and Kues, G.E., 1999, Ground-water quality and susceptibility of ground water to effects from domestic wastewater disposal in eastern Bernalillo County, eastern New Mexico, 1990-91: U. S. Geological Survey Water Resources Investigation Report 99-4096, 109 p.

Burt, T.P., Bates, P.D., Stewart, M.D., Claxton, A.J., Anderson, M.G., and Price, D.A., 2002, Water table fluctuations within the floodplain of the River Severn, England: Journal of Hydrology, v. 262, p. 1-20.

Davis, J.C., 2002, Statistics and Data Analysis in Geology: New York, NY, John Wiley and Sons, 638 p.

Diggle, P.D., 1990, Time Series-A Biostatistical Introduction: Oxford, Oxford Science Publications, 244 p.

Drakos, P., Lazarus, J., Jetter, S., and Hodgins, M., 1999, Hydrogeologic characterization of fractured Abo and Madera formation aquifers, hydrocarbon contamination and transport along the Zuzax fault, Tijeras Canyon, New Mexico, in New Mexico Geological Society Guidebook, 50 ${ }^{\text {th }}$ Field Conference, September 22-25, 1999: [Albuquerque, N. Mex.], Albuquerque Geology, p. 419-424.
Ferguson, C.A., Timmons, J.M., Pazzaglia, F.J., Karlstrom, K.E., Osburn, G.R., and Bauer, P.W., 1996, Geology of the Sandia Park 7.5-minute quadrangle, Bernalillo and Sandoval Counties, New Mexico: New Mexico Bureau of Mines and Mineral Resources, Open-file Geologic Map OF-GM 1, scale 1:24,000. [Last revised August 31, 1999.]

Fetter, C.W., 1988, Applied Hydrogeology: Upper Saddle River, New Jersey, Prentice Hall, 691p.

Florea, L.J., and Vacher, H.L., 2006, Springflow hydrographseogenetic vs. telogenetic karst: Ground Water, v. 44, no. 3 , p. 352-361.

Green, G.N., and Jones, G.E., 1997, The digital map of New Mexico in Arc/Info format: U.S. Geological Survey OpenFile Report 97-52, 9 p.

Hem, J.D., 1985, Study and interpretation of the chemical characteristics of natural water (3d ed.): U.S. Geological Survey Water-Supply Paper 2254, 263 p.

Johnson, P., 1998, Surface-water assessment, Taos County, New Mexico-Administrative Report to New Mexico Interstate Stream Commission: place of publication, New Mexico Bureau of Mines and Mineral Resources, variously paginated.

Karlstrom, K.E., Connell, S.D., Ferguson, C.A., Read, A.S., Osburn, G., Kirby, E., Abbott, J.C., Hitchcock, C., Kelson, K.I., Noller, J., Sawyer, T., Ralser, S., Love, D.W., Nyman, M., and Bauer, P.W., 1994, Geology of the Tijeras quadrangle, Bernalillo County, New Mexico: New Mexico Bureau of Mines and Mineral Resources, Openfile Geologic Map OF-GM 4, scale 1:24,000. [Last revised April 5, 2000.]

Kelley, V.C., and Northrop, S.A., 1975, Geology of Sandia Mountains and Vicinity, New Mexico: New Mexico Bureau of Mines and Mineral Resources, Memoir 29, 136 p.

Kues, G.E., 1990, Ground-water availability and quality in eastern Bernalillo County and vicinity, central New Mexico: U.S. Geological Survey Water-Resources Investigations Report 89-4127, 82 p.

Kues, G.E., and Garcia, B.M., 1995, Ground-water quality and ground-water-level data, Bernalillo County, central New Mexico, 1990-93: U.S. Geological Survey Open-File Report 95-385, $76 \mathrm{p}$ 
Larocque, M., Mangin, A., Razack, M., and Banton, O., 1998, Contribution of correlation and spectral analyses to the regional study of a large karst aquifer (Charente, France): Journal of Hydrology, v. 205, p. 217-231.

Lee, L.J.E., Lawrence, D.S.L., and Price, M., 2006, Analysis of water-level response to rainfall and implications for recharge pathways in the Chalk aquifer, SE England: Journal of Hydrology, v. 330, p. 604-620.

Lee, J-Y., and Lee, K-K., 2000, Use of hydrologic time series data for identification of recharge mechanism in a fractured bedrock aquifer system: Journal of Hydrology, v. 229, p. 190-201.

National Research Council, 1996, Rock fractures and fluid flow: National Academy Press, Washington, D.C., 551 p.

National Oceanic and Atmospheric Administration, 2007, Web Climate Services, Asheville, N.C., National Climatic Data Center, National Oceanic and Atmospheric Administration: accessed January 15, 2007, at http://www.ncdc.noaa.gov/oad climate/stationlocator.htm

Phillips, F.M., 1994, Environmental tracers for water movement in desert soils of the American Southwest: Soil Science Society of America Journal, v. 58, p. 15-24.
Rankin, D.R., 2000, Water-quality and ground-water-level trends, 1990-99, and data collected from 1995 through 1999, east mountain area, Bernalillo County, central New Mexico: U.S. Geological Survey Open-File Report 00-476, $41 \mathrm{p}$.

Read, A.S., Karlstrom, K.E., Connell, S.D., Kirby, E., Ferguson, C.A., Ilg, B., Osburn, G.R., Van Hart, D., Pazzaglia, F.J., 1995, Geology of the Sandia Crest quadrangle, Bernalillo and Sandoval Counties, New Mexico: New Mexico Bureau of Mines and Mineral Resources, Open-file Geologic Map OF-GM 6, scale 1:24,000. [Last revised February 2, 2000.]

Titus, Frank B., 1980, Ground water in the Sandia and northern Manzano Mountains, New Mexico: New Mexico Bureau of Mines and Mineral Resources Hydrologic Report $5,66 \mathrm{p}$.

Wasiolek, M., 1995, Subsurface recharge to the Tesuque aquifer system from selected drainage basins along the western side of the Sangre de Cristo Mountains near Santa Fe, New Mexico: U.S. Geological Survey Water-Resources Investigations Report 94-4072, 57 p.

White, W.D., and Kues, G.E., 1992, Inventory of springs in the state of New Mexico: U.S. Geological Survey Open-File Report 92-118, 253 p. 


\section{Appendix 1. Monthly Precipitation Totals for U.S. Geological Survey-operated Weather Stations in Eastern Bernalillo County, N. Mex.}

Appendix 1. Monthly precipitation totals for U.S. Geological Survey-operated weather stations in eastern Bernalillo County, N. Mex [Site locations shown in fig. 1. Abbreviations: ND, no data; bold values, more than 10 days of data missing]

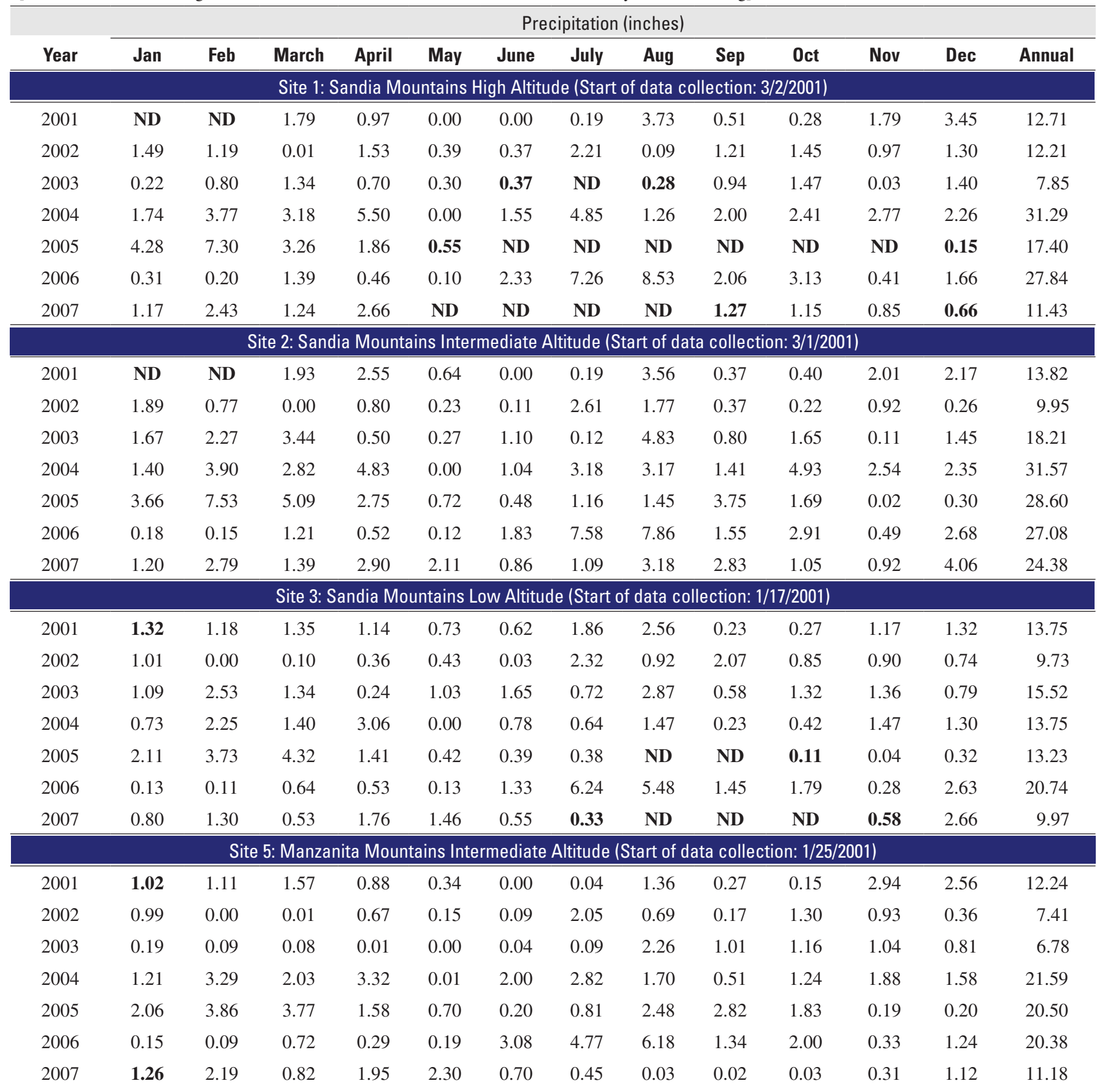


Appendix 1. Monthly precipitation totals for U.S. Geological Survey-operated weather stations in eastern Bernalillo County, N. Mex.-Continued

[Site locations shown in fig. 1. Abbreviations: ND, no data; bold values, more than 10 days of data missing]

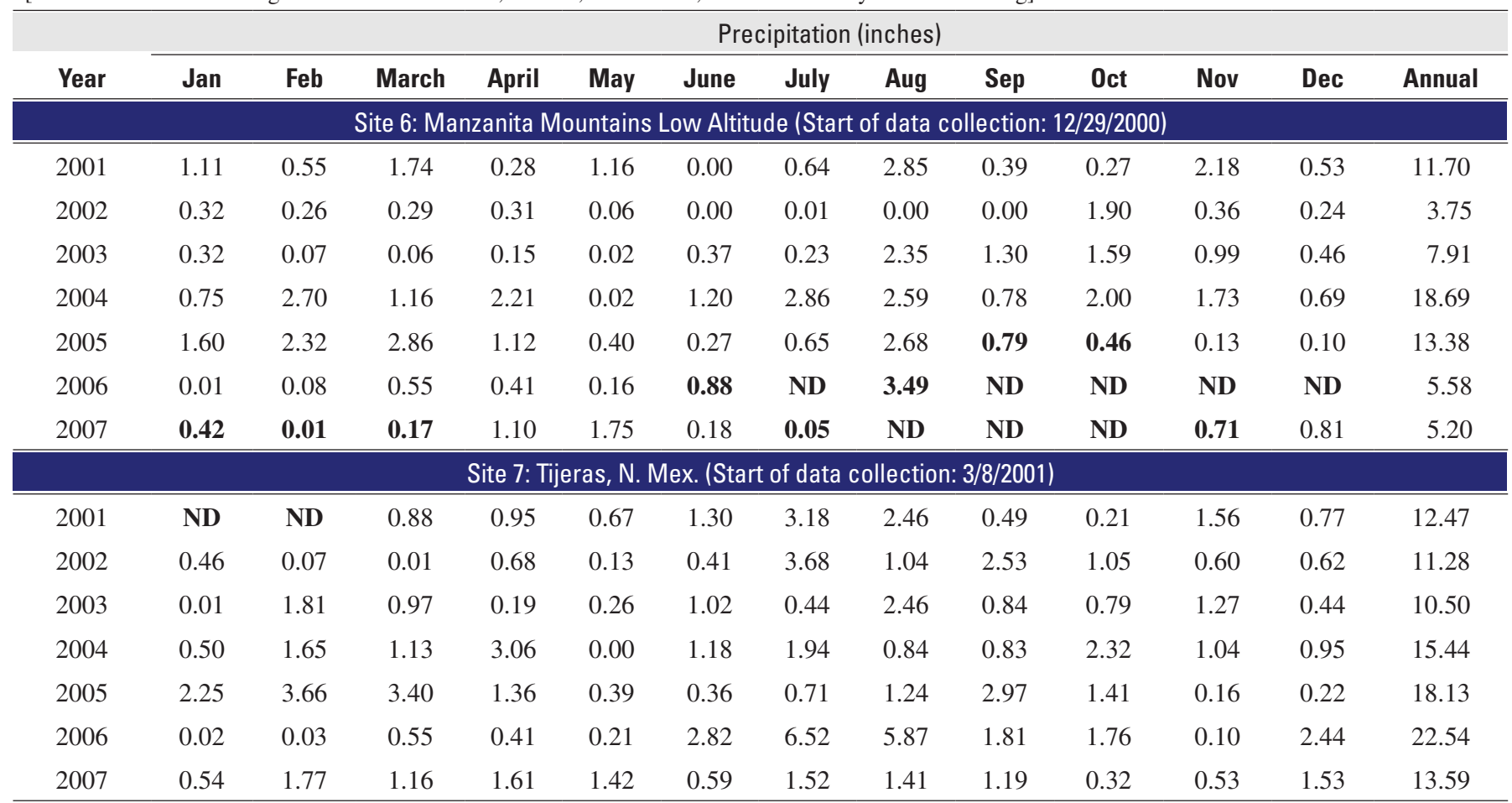




\section{Appendix 2. Specific Conductance and Dissolved Chloride Concentration from Springs Sampled in Eastern Bernalillo County, N. Mex.}

Appendix 2. Specific conductance and dissolved chloride concentration from springs sampled in eastern Bernalillo County, N. Mex.

[Site locations shown in fig. 1. Abbreviations: mg/L, milligrams per liter; $\mu \mathrm{S} / \mathrm{cm}$, microsiemens per centimeter; --, not measured]

\begin{tabular}{|c|c|c|c|c|}
\hline Site number & Station number & Date & Dissolved chloride (mg/L) & Specific conductance ( $\mathrm{s} / \mathrm{cm})$ \\
\hline \multirow[t]{11}{*}{45} & 351022106231401 & $03 / 10 / 05$ & 15.00 & 570 \\
\hline & & $04 / 06 / 05$ & 19.00 & 750 \\
\hline & & 04/27/05 & 32.60 & 795 \\
\hline & & $05 / 18 / 05$ & 31.40 & 800 \\
\hline & & $06 / 29 / 05$ & 14.40 & 790 \\
\hline & & $12 / 29 / 05$ & 39.00 & 750 \\
\hline & & $02 / 28 / 06$ & 40.40 & -- \\
\hline & & 04/04/06 & 41.50 & 720 \\
\hline & & 08/31/06 & 40.50 & 720 \\
\hline & & 09/26/07 & 36.60 & 720 \\
\hline & & $12 / 04 / 07$ & 4.33 & 457 \\
\hline \multirow[t]{13}{*}{46} & 350518106235701 & 03/08/05 & 1.63 & -- \\
\hline & & $04 / 12 / 05$ & 1.73 & -- \\
\hline & & $04 / 29 / 05$ & 1.90 & 450 \\
\hline & & $05 / 24 / 05$ & 1.92 & 460 \\
\hline & & 06/29/05 & 1.94 & 470 \\
\hline & & 09/01/05 & 1.65 & 470 \\
\hline & & $12 / 30 / 05$ & 1.69 & 480 \\
\hline & & 03/14/06 & 1.75 & 470 \\
\hline & & 04/12/06 & 1.63 & 470 \\
\hline & & $06 / 21 / 06$ & 1.63 & 480 \\
\hline & & 08/28/06 & 1.65 & 470 \\
\hline & & 09/28/07 & 1.61 & 460 \\
\hline & & $12 / 11 / 07$ & 1.69 & 479 \\
\hline \multirow[t]{11}{*}{47} & 350850106232001 & $04 / 05 / 05$ & 1.68 & 550 \\
\hline & & $04 / 29 / 05$ & 1.67 & 550 \\
\hline & & $05 / 20 / 05$ & 1.73 & 550 \\
\hline & & 06/30/05 & 1.63 & 540 \\
\hline & & 08/31/05 & 1.62 & 550 \\
\hline & & $12 / 28 / 05$ & 1.51 & 550 \\
\hline & & 03/01/06 & 1.48 & 540 \\
\hline & & 04/05/06 & 1.59 & 540 \\
\hline & & 08/26/06 & 1.45 & 540 \\
\hline & & 09/28/07 & 1.31 & 530 \\
\hline & & $12 / 04 / 07$ & 1.45 & 534 \\
\hline
\end{tabular}


Appendix 2. Specific conductance and dissolved chloride concentration from springs sampled in eastern Bernalillo County, N. Mex.-Continued

[Site locations shown in fig. 1. Abbreviations: mg/L, milligrams per liter; $\mu \mathrm{S} / \mathrm{cm}$, microsiemens per centimeter; --, not measured]

\begin{tabular}{|c|c|c|c|c|}
\hline Site number & Station number & Date & Dissolved chloride (mg/L) & Specific conductance $(\mu \mathrm{S} / \mathrm{cm})$ \\
\hline \multirow[t]{11}{*}{48} & 350807106231701 & $04 / 05 / 05$ & 1.97 & 600 \\
\hline & & $04 / 27 / 05$ & 2.07 & 610 \\
\hline & & 05/20/05 & 2.29 & 630 \\
\hline & & $06 / 30 / 05$ & 2.29 & 630 \\
\hline & & 09/01/05 & 2.21 & 630 \\
\hline & & $12 / 28 / 05$ & 2.07 & 630 \\
\hline & & 03/01/06 & 1.97 & 610 \\
\hline & & $04 / 05 / 06$ & 2.09 & 610 \\
\hline & & 08/29/06 & 1.94 & 600 \\
\hline & & 09/25/07 & 1.88 & 590 \\
\hline & & $12 / 04 / 07$ & 1.93 & 604 \\
\hline \multirow[t]{12}{*}{49} & 351008106231601 & $04 / 21 / 05$ & 2.43 & 570 \\
\hline & & $04 / 27 / 05$ & 3.46 & 570 \\
\hline & & 05/18/05 & 7.20 & 580 \\
\hline & & 06/29/05 & 15.80 & 590 \\
\hline & & 09/01/05 & 20.70 & 600 \\
\hline & & $12 / 29 / 05$ & 19.60 & 590 \\
\hline & & $02 / 28 / 06$ & 18.60 & -- \\
\hline & & $04 / 04 / 06$ & 18.40 & 580 \\
\hline & & $06 / 21 / 06$ & 16.90 & 560 \\
\hline & & 08/31/06 & 5.10 & 570 \\
\hline & & 09/14/07 & 16.00 & 580 \\
\hline & & $12 / 04 / 07$ & 15.82 & 466 \\
\hline
\end{tabular}


Publishing support provided by the Lafayette Publishing Service Center for the New Mexico Water Science Center 
